\title{
ALUMINUM RECOVERY FROM COAL FLY ASH BY HIGH TEMPERATURE CHLORINATION
}

Hendra Wijatno

M. S. Thesis Submitted to Iowa State University

$$
\begin{aligned}
& \text { Ames Laboratory, DOE } \\
& \text { Iowa State University } \\
& \text { Ames, Iowa } 50011
\end{aligned}
$$

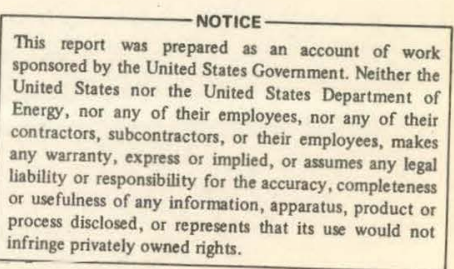

This report was prepared as an account of work United Sthe United States Government. Neither the Energy, nor contractors, subcontractors, or their employees, makes or usefulness of any information, apparatus, product or infringe privasely or represents that its use would not

Date Transmitted: October 1977

PREPARED FOR THE U.S. DEPARTMENT OF ENERGY UNDER CONTRACT NO. W-7405-eng-82 


\section{DISCLAIMER}

This report was prepared as an account of work sponsored by an agency of the United States Government. Neither the United States Government nor any agency Thereof, nor any of their employees, makes any warranty, express or implied, or assumes any legal liability or responsibility for the accuracy, completeness, or usefulness of any information, apparatus, product, or process disclosed, or represents that its use would not infringe privately owned rights. Reference herein to any specific commercial product, process, or service by trade name, trademark, manufacturer, or otherwise does not necessarily constitute or imply its endorsement, recommendation, or favoring by the United States Government or any agency thereof. The views and opinions of authors expressed herein do not necessarily state or reflect those of the United States Government or any agency thereof. 


\section{DISCLAIMER}

Portions of this document may be illegible in electronic image products. Images are produced from the best available original document. 
This report was prepared as an account of work sponsored by the United States Government. Neither the United States nor the United States Department of Energy, nor any of their employees, nor any of their contractors, subcontractors, or their employees, makes any warranty, express or implied, or assumes any legal liability or responsibility for the accuracy, completeness, or usefulness of any information, apparatus, product or process disclosed, or represents that its use would not infringe privately owned rights.

Available from: National Technical Information Service

U. S. Department of Commerce

P.O. Box 1553

Springfield, VA 22161

Price: Microfiche $\$ 3.00$ 


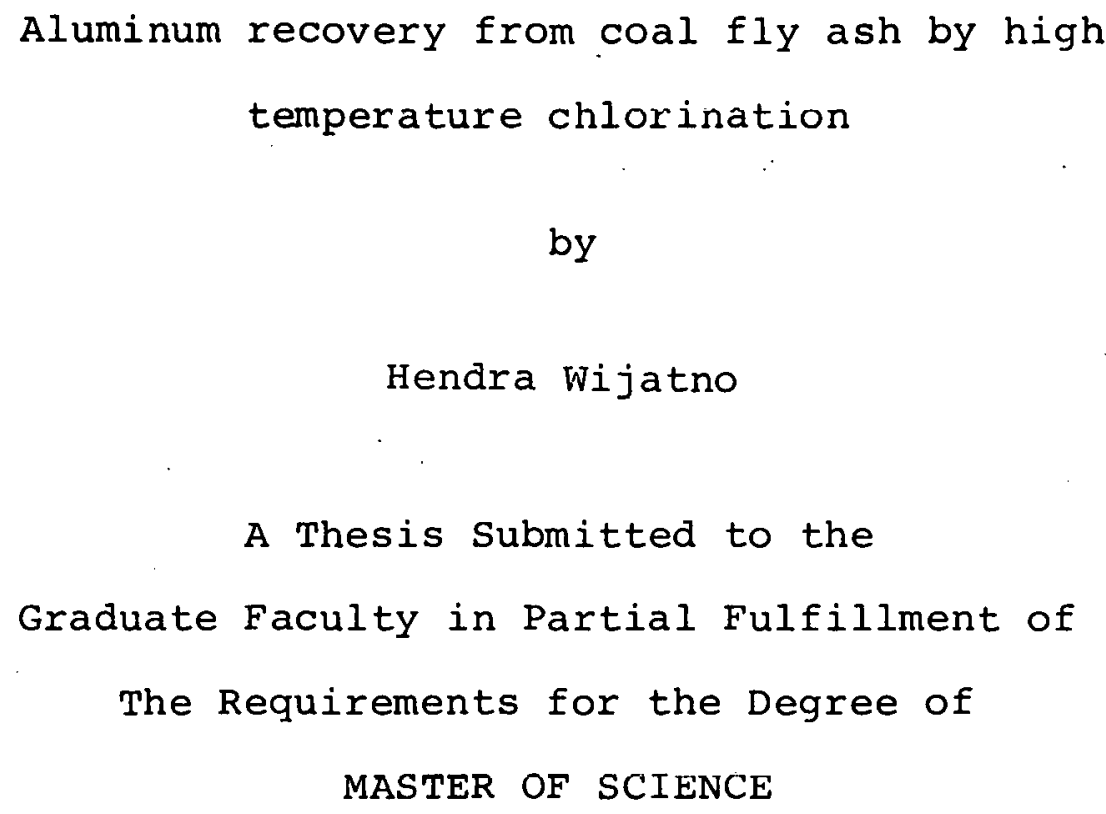

A Thesis Submitted to the Graduate Faculty in Partial Fulfillment of The Requirements for the Degree of MASTER OF SCIENCE
Department: Chemical Engineering and Nuclear Engineering
Major: Chemical Engineering
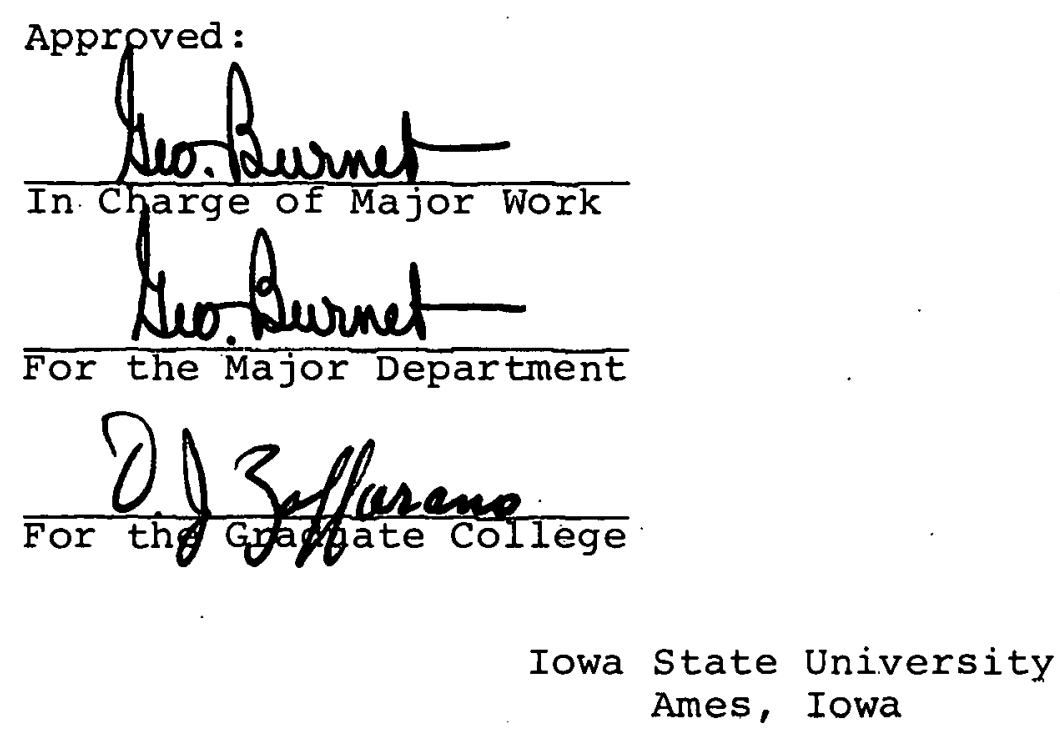
TABLE OF CONTENTS

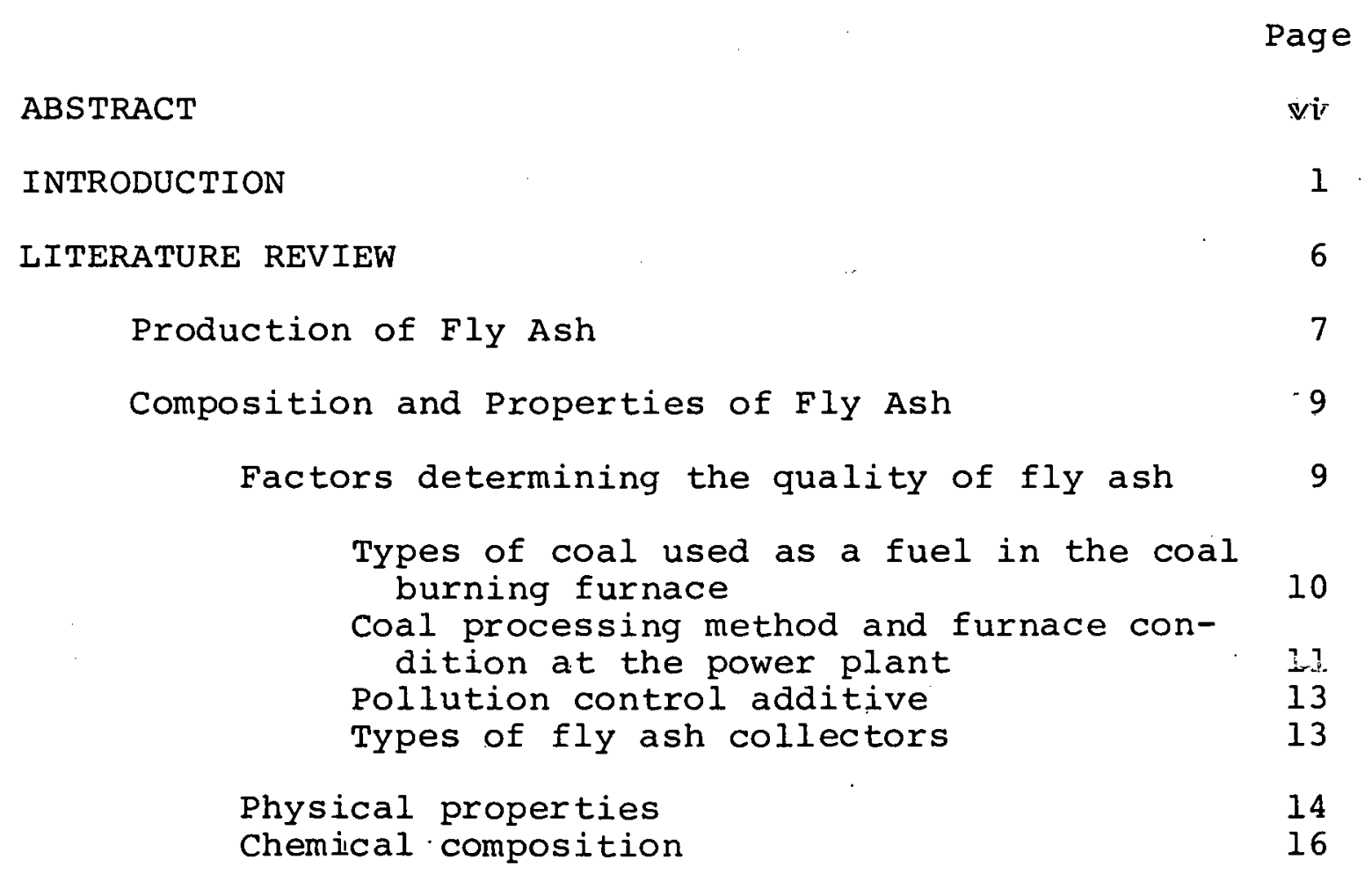

Utilization of and Current Research on Fly Ash in the United States

Recovery of Alumina from Bauxite 20

$\begin{array}{ll}\text { Alumina Recovery from Clay } & 23\end{array}$

Acid processes $\quad 24$

Sulfuric acid process 25

Hydrochloric acid process . 26

$\begin{array}{ll}\text { Nitric acid process } & 27\end{array}$

$\begin{array}{ll}\text { Ammonium alum process } & 27\end{array}$

Potassium alum process $\quad 28$

Sintering process $\quad 29$

Toth process 31

H-plus process $\quad$. . . 31

Iron and Alumina Recovery from Fly Ash 32 
Page

Magnetic separation of the iron

Sintering and acid processes for alumina recovery from fly ash

High Temperature Chlorination of Fly Ash 34

EXPERIMENTAL PROCEDURE 39

Material $\quad 39$

Magnetic Separation $\quad 41$

Quantitative Analysis $\quad 44$

Preparation of Ash Samples $\quad 44$

High Temperature Chlorination $\quad 45$

Photomicroscopic Observations of Ash Samples $\quad 47$

Analysis of the Chloride Products . 47

$\begin{array}{ll}\text { DISCUSSION OF RESULTS } & 49\end{array}$

Results of Magnetic Separation $\quad 49$

Results of Chlorinating the Iron Oxide at Low
Temperature

Results of Photomicroscopic Observations of Ash Samples $\quad 52$

Results of the Effect of High Temperature
Chlorination Variables

Effect of reaction time and temperature 57

Effects of chlorine flow rate and temperature 66

CONCLUSIONS $\quad 70$

$\begin{array}{ll}\text { RECOMMENDATIONS } & 72\end{array}$

$\begin{array}{ll}\text { REFERENCES } & 74\end{array}$

$\begin{array}{lr}\text { ACKNOWLEDGMENTS } & 82\end{array}$ 
ABSTRACT ${ }^{1}$

A study of aluminum recovery from power plant fly ash by high temperature chlorination was undertaken to demonstrate that fly ash could be a potential source of aluminum, iron and possibly silicon. Magnetic separation of the iron oxide served as a first step to alleviate the iron contamination problem. However, the agglomeration of some iron oxide with alumina and silica made it difficult to completely separate the iron from the fly ash. Further iron separation was achieved by chlorinating the nonmagnetic ash fraction at $550^{\circ} \mathrm{C}$ for 30 minutes. This reduced the iron oxide content to less than $4 \%$ by weight. Chlorine flow rates affected the reaction rate much more drastically than temperatures. This suggested that diffusion was the major rate-controlling step. Besides $\mathrm{Fe}_{2} \mathrm{O}_{3}$, $\mathrm{Al}_{2} \mathrm{O}_{3}$ and $\mathrm{SiO}_{2}$, other oxides such as $\mathrm{CaO}, \mathrm{K}_{2} \mathrm{O}, \mathrm{Na}_{2} \mathrm{O}$ and $\mathrm{MgO}$ might have complicated the alumina recovery by forming individual chlorides or complexes. Investigating methods for separating more $\mathrm{Fe}_{2} \mathrm{O}_{3}$, and possibly CaO, $\mathrm{K}_{2} \mathrm{O}, \mathrm{Na}_{2} \mathrm{O}$ and $\mathrm{MgO}$ from the nonmagnetic ash fraction before chlorinating it is highly recommended.

${ }^{1}$ USAEC Report IS-T-777. This work was performed under Contract W-7405-eng-82 with the Energy Research and Development Aamiisislialiun. 


\section{INTRODUCTION}

The day of cheap and abundant energy is past. The late 1973 Arab oil embargo plunged much of the world into an economic depression and signalled a warning, especially to industrialized countries that energy sources, primarily oil, have become a serious problem. Since then, other raw material producing countries have realized that their valuable natural resources, mineral, for example, also will eventually run out.

Energy is the backbone of modern society (8). Its pervasive influence on virtually every aspect of our lives had evolved in such a way that few realized the magnitude of our dependency on it until the Arab oil embargo. With only $10 \%$ of the world's population, the United States accounts for about $35 \%$ of the world's annual energy consumption (8). As a big energy consumer, the United States relies very heavily on foreign sources. According to a summary of a United States Geological Survey report (41), imports of oil and natural gas account for about $29 \%$ of this country's requirements. The National Research Council $(52,73)$ estimates that the United States has about 113 billion barrels of undiscovered, recoverable oil and equivalent natural gas resources. If known reserves are added, the total comes to 150 billion barrels of oil and no more than 600 trillion cubic feet of natural gas. Current United States consumption of oil and natural gas liquids is about 6 billion barrels 
per year and that of natural gas is about 23 trillion. cubic feet per year. Energy consumption in the United States has been increasing an average of $2.9 \%$ annually over the last 30 years. Based on these statistics, the United states eventually will be out of oil in 18 years and of natural gas in about 20 years.

This shortage problem is not limited to natural gas and oil. Other mineral resources also are in danger of running out (52). In fact, a new United States Geological Survey report (3) has confirmed that the United States is going to face a shortage of minerals in the "foreseeable future." Specifically, in 1974 the United States was more than $90 \%$ dependent on imports of primary materials for seven commodities (manganese, cobalt, chromium, titanium, niobium, strotium, and sheet mica); 75 to $90 \%$ on eight other commodities (aluminum, platinum, tin, tantalum, bismuth, fluorine, asbestos, and mercury), and 50 to $75 \%$ on another eight commodities (zinc, gold, silver, tungsten, nickel, cadmium, selenium, and potassium). This dependency makes the United States vulnerable to cartel agreements amóng the major producing nations (3).

To lessen its vulnerability to overseas supplies, the United states must not only turn to more recycling! conservation and new technology, but also use of resources 
that currently are either in subeconomic deposits or in deposits yet to be discovered (41). The United States must undertake research programs on mining and extraction techniques that will raise the efficiency of processes for obtaining vital materials from lower-grade domestic ores and developing substitute materials and exploring their effects on product design and performance. Such research need not yield economic processes or products in the current market. Instead the research would give the United States an available technology that could be scaled up and brought on stream if normal supplies were in jeopardy (73).

Turning to aluminum, the universal way for making this metal is the Bayer-Hall process, which requires high-grade bauxite, an essentially silica-free alumina hydrate. Nevertheless, a variety of pressures; economic and political, slowly are pushing the world aluminum industry toward unconventional aluminum processes (63). Indeed, there has been concern over the United States heavy dependency on foreign sources of bauxite.

Since World War II, efforts have been made in the United States to investigate various types of processes that might bear the possibility of utilizing the lowgrade ores of aluminum that are more plentiful than bauxite (23). During World War II, the United States Defense Plant 
Corporation financed the construction of a 50 ton-a-day plant at Laramie, Wyoming, to produce alumina from anorthosite, a form of low-grade ore (33). Since then, there has been substantial research reported by the United States Bureau of Mines on producing alumina from clay $(31,32,33,55$, $56,57,58,59,60,61)$. In 1973, Applied Aluminum Research Corporation, New Orleans, revealed the Toth process which claims to be able to use many sources of alumina apart from bauxite (47). In 1974, France's Pechiney Ugine Kuhlman and the Aluminum Company of Canada disclosed the new H-plus process for handling nonbauxite ores. The Aluminum Company of America, Reynolds Metals Company and Earth Sciences, Incorporated, also announced their respective tests on recovering alumina from low-grade ores (1, 63).

Common to all current research into mineral resource supplies is an awareness that current sources of domestic minerals have only a limited duration before they are completely exhausted. The situation may become analogous to the one involving the world's petroleum output. It is now becoming increasingly important for the United states to advance a technology and investigate new sources of domestic mineral supply.

It is the purpose of this thesis to examine and explore the potential for utilizing power plant fly ash as an 
alternative source of domestic aluminum and iron. The research is focused on the extraction process of alumina from the nonmagnetic part of fly ash. The magnetic part, which is rich in iron, can be used as a source of iron. Such a process will hopefully create a source of metals, particularly aluminum, and hence alleviate the existing burden on limited and dwindling mineral resources in the United states. In addition, the solid fly ash wastes, which have long been a disposal problem for coal-burning power plants, will be more efficiently utilized. 


\section{LITERATURE REVIEW}

For the next 25 years, coal, primarily, and nuclear power seem to be the likely energy options of the United States (8). Natural oil and gas, geothermal, hydrothermal and solar energy will play important but comparatively minor roles. In spite of an impressive record to date, the future of nuclear power is unfortunately very much in doubt (8). Solar, geothermal and energy of other forms may constitute only 3 to $4 \%$ of this country's needs by 1985 (18). Increased energy production in the forseeable future will come from the burning of coal (45). Coal is the most abundant domestic fossil resource sufficient to meet the nation's needs for an estimated 200 years (8). It is predicted (18) that by 1985, coal will provide the United States a third of its energy requirements if coal production is doubled from the current 600 million tons a year to 1.2 billion tons a year.

Widespread use of the pulverized fuel burner since its introduction in 1920 's has caused negative effects on the environment. The burner, although operating efficiently and economically, produces solid wastes which can cause air pollution problems. These solid wastes that are discharged in the flue gases of the power generating facilities are called fly ash. 
Production of Fly Ash

Fly ash (10) has been defined more completely as a product of combustion, chiefly the product of burning pulverized coal and to some extent the burning of residual oils in large industrial or power boilers. As pulverized coal is burned, fly ash is formed from the incombustible components in the coal and from those particles of coal that are not burned due to incomplete combustion within the furnace proper.

The invention of the pulverized coal burning furnace has produced significant amounts of fly ash that have found relatively limited use. Morrison (45) reported that during 1975, the electric utility industry in the United States burned approximately 410 million tons of coal. The corresponding ash production was nearly 63 million tons of which 41 million tons was fly ash. This accounts for only $80 \%$ of the total coal consumption in this country (11). The ash consumption, however, is only about $16.3 \%$ of the total amount of ash produced (25).

The projected outlook for ash production is shown in Figure 1 (11). Brackett (11) and Faber (25) attribute the projected increase in ash production to three factors:

(1) Increased utilization of higher ash containing coals. 


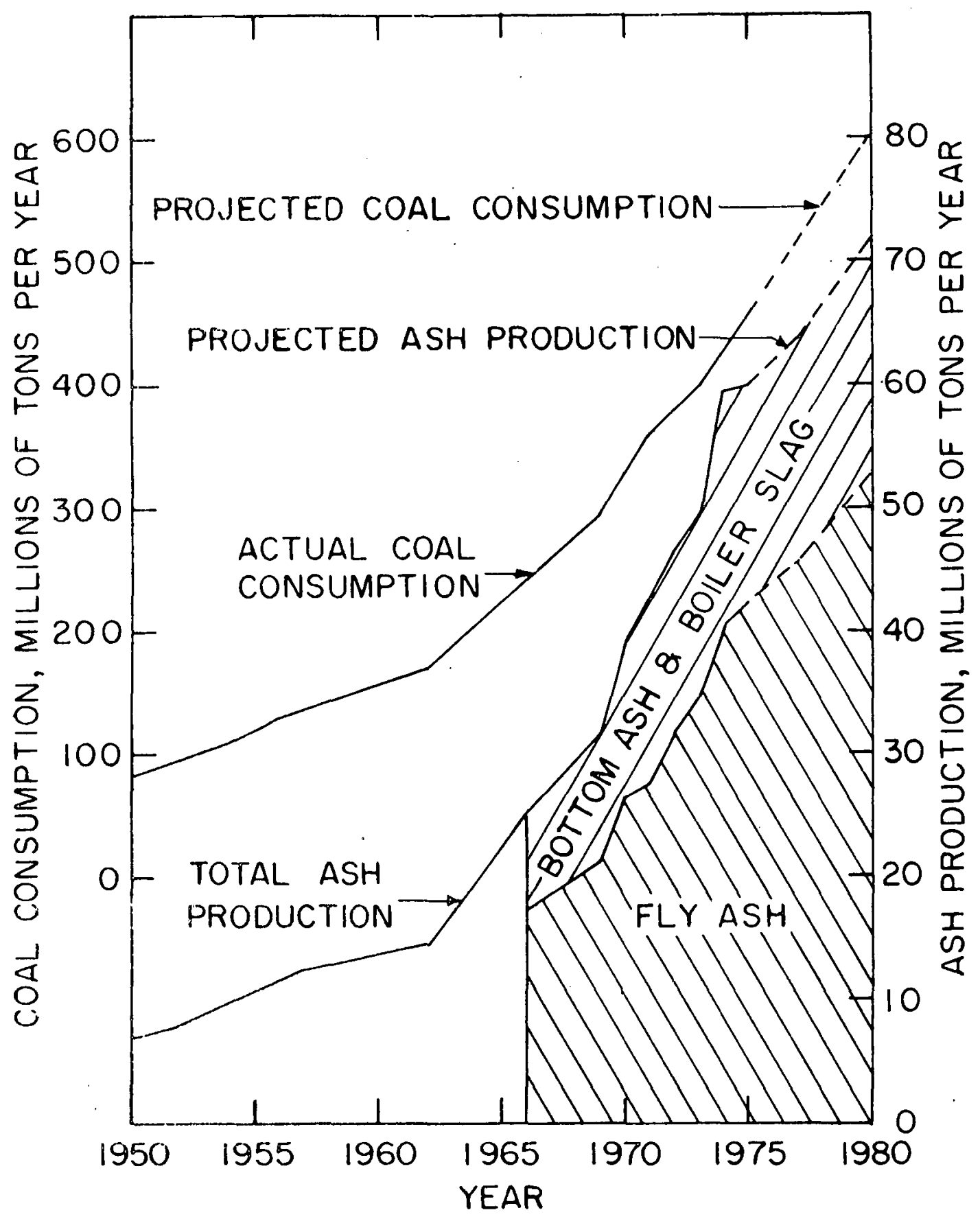

Figure 1. Coal consumption and ash production by United States electric utilities (1l) 
(2) The conversion from coal to oil usage and employment of lignite coals.

(3) The development and utilization of more efficient ash collection devices.

Figures compiled for the United States Department of Interior's 1974 Mineral Yearbook (25) rank ash the nation's seventh most abundant solid mineral, just behind stone, sand/gravel, coal, iron ore, portland cement and clays.

\section{Composition and Properties of} Fly Ash

Factors determining the quality of fly ash

Fly ash is widely diverse in its physical and chemical properties. The extraction of alumina or iron from fly ash depends highly on its composition and thus, factors affecting the ash quality deserve attention. Broadly speaking, factors determining the quality of fly ash are $(10,16,34):$

1. Types of coal used as a fuel in the coal burning furnace;

2. Coal processing methods and furnace conditions at the power plant;

3. Pollution control additive;

4. Types of fly ash collectors: 
Types of coal used as a fuel in the coal burning furnace

Coal may be classified into two groups based on the nature of their ash constituents (45). One is the bituminoustype ash and the other the lignite-type ash. The term "lignite-type" ash is defined as an ash having more calcium oxide ( $\mathrm{CaO})$, plus magnesium oxide (MgO), than ferric oxide $\left(\mathrm{Fe}_{2} \mathrm{O}_{3}\right)$. By contrast, the "bituminous-type" ash will have more ferric oxide, than calcium oxide, plus magnesium oxide (45).

Coals used in power plants may contain up to $25 \%$ incombustible mineral matter classified as inherent or extraneous $(34,46)$. Inherent mineral matter is defined as the content of the coal that is structurally and organically part of the coal itself. It usually cannot be separated from the coal by mechanical means. Extraneous mineral matter is that which was introduced into the coal beds subsequent to formation, as well as any mineral contamination deposits by winds and water into the joints and crevices of coal seams. Mechanical separation of the extraneous mineral matter is possible.

Analysis of a number of United States coals for mineralogical composition has been reported by Nelson (46), Ball (7) and Gumz (30). They show that 958 of the mineral matter is composed of kaolinite $\left(\mathrm{Al}_{2} \mathrm{O}_{3} \cdot 2 \mathrm{SiO}_{2} \cdot 2 \mathrm{H}_{2} \mathrm{O}\right)$, pyrite 
(cubic $\left.\mathrm{FeS}_{2}\right)$, and calcite $\left(\mathrm{CaCO}_{3}\right)$. The general range of composition is as follows: kaolinite 70-95\%; pyrite 5-35\%; calcite 0-20\%. The other identifiable minerals in coal include marcasite (orthorhombic $\mathrm{FeS}_{2}$ ), chalcopyrite $\left(\mathrm{CuFeS}_{2}\right)$, arsenopyrite (FeAsS), stibnite $\left(\mathrm{Sb}_{2} \mathrm{~S}_{3}\right)$, gypsum $\left(\mathrm{CaSO}_{4} \cdot 2 \mathrm{H}_{2} \mathrm{O}\right)$, quartz $\left(\mathrm{SiO}_{2}\right)$, dolomite $\left(\mathrm{CaMg}\left(\mathrm{CO}_{3}\right)_{2}\right)$, apatite $\left(\mathrm{Ca}_{5}\left(\mathrm{PO}_{4}\right)_{3} \mathrm{~F}\right)$ and mica (15).

Coal processing method and furnace condition at the power plant Brackett (10) states that most pulverizers are designed to produce a pulverized coal product 80 to $85 \%$ of which will pass a 74 micron (200-mesh) screen and $98 \%$ of which will pass 297 micron (50-mesh) screen. The main objective of pulverizing the coal is to increase the surface area. This reduces the burning time while increasing the rate of heat generated per unit volume (71). The finer the coal is crushed, the fewer the number of particles that will remain unburnt. The resulting fly ash will also become finer (10). Littlejohn (39) studied the mineral characteristics in individual coal particles as a function of size. On the basis of pulverized coal "as fired" he was able to classify particle as (34):

(a) clean coal particles containing only inherent mineral matter and less than $2 \%$ ash. 
(b) mixed particles containing both clean coal and extraneous minerals and

(c) discrete mineral particles.

Littlejohn (39) also found that as the coal particle size decreased, the proportion of clean coal decreased, and that the proportion of mixed particles and that of discrete mineral fragments increased.

Nelson (46) and Gumz (30) presented detailed studies on the atmosphere, temperature and particle residence time in suspension-fired coal furnaces. To achieve proper combustion and to keep the coal particles in suspension, air, 20 to $25 \%$ in excess, is employed $(10,71)$. Flame temperatures vary from $1,300^{\circ} \mathrm{C}$ to $1,700^{\circ} \mathrm{C}(30,46,79)$. Air injection of pulverized coal forces the particles into the flame at a minimum velocity of 60 feet per second (71). The residence time of the particles is less than two seconds $(27,34)$. Within this short period of time, mineral particles in the pulverized coal are heated to a maximum temperature with accompanying physical and chemical changes. These resulting particles, termed "slagged" in the literature, are quenched into glassy spheres which are exhausted in the stream of gases $(10,34,46)$.

Clendenning and Durie (17) found trat due to the high particle velocity, 5 to $20 \%$ of the coal particles pass 
through the furnace unoxidized. They also observed that different velocities of the injected air will resulted in different carbon contents and fineness of the fly ash formed. Reducing the velocity increases the carbon content and the ash fineness. Watt and Thorne $(76,77)$ made some studies on coal fly ash and reported different mineral matter will result in different fly ash particles. The unburnt coal particles, usually irregular in shape, are dark and 20 to 200 micron in size. Particles formed from kaolinite $\left(\mathrm{Al}_{2} \mathrm{O}_{3} \cdot \mathrm{SiO}_{2} \cdot 2 \mathrm{H}_{2} \mathrm{O}\right)$ are white or colorless; they appear as solid glassy spheres. Some spheres are hollow and are termed cenospheres. Pyrite $\left(\mathrm{FeS}_{2}\right)$ oxidizes to iron oxide and gaseous sulfur oxide. The iron oxide particles are black or reddish in color and may be spherical or spongy. They appear in crystalline form $(34,76,77)$.

Pollution control additive To increase the efficiency of flue gas scrubbers by reducing the level of sulfur dioxide emitted, powdered limestone or dolomite has been added to the pulverized coal. The $\mathrm{SO}_{2}$ gas then reacts with CaO or Mgo to form $\mathrm{CaSO}_{4}$ or $\mathrm{MgSO}_{4}$. This addition of limestone or dolomite will change the composition of resulting fly ash (34).

\section{Types of fly ash collectors The usual types of} particulate removal equipment are electrostatic precipitator, mechanical dust collectors, fabric filters and wet scrubbers. 
Mechanical dust collectors, although they have an efficiency of about $90 \%$, are insufficient for large high-capacity power plant and not very effective for particles smaller than 10 microns (5). Electrostatic precipitators can achieve an efficiency of 99\% (34). However, Brackett (10) and styron (70) found that halloysite, $\mathrm{Al}_{2}\left(\mathrm{Si}_{2} \mathrm{O}_{5}\right)(\mathrm{OH})_{4}$, which is a hydrated analog of kaolinite, is a very efficient electrical insulator. In passing through the combustion process, halloysite changes its form but not its properties. As it leaves the boiler and starts to cool, it picks up moisture and forms a coating which insulates the surface of the electrical components of the electrostatic precipitators. When the insulating coating forms, it makes it difficult to collect the fly ash electrostatically (16).

\section{Physical properties}

Fly ash contains 11 to $48 \%$ crystalline matter, the rest being amorphous material and carbon particles. Quartz, mullite, hematite and magnetite from the major portion of the crystalline matter $(34,76,77)$. When fly ash is examined microscopically, it may be observed to consist of particles varying in shape and size. The average size varies from less than 1 micron to approximately 80 microns $(10,39,42,76)$. Some carbonaceous particles (10), however, can be more than 300 microns in size. Watt and Thorne (76) found that the 
weight distribution of the samples of different sizes is approximately linear in a logarithmic probability plot. This implies a Gaussian distribution. They further observed that finer particles were much more numerous than larger ones, but they contribute much less to the weight. In a particular ash studied, more than $60 \%$ of the particles numerically had diameters less than 3 microns but these particles contributed less than $10 \%$ of the total weight (76). Minnick (42) inferred from his analysis that the finer fraction of the ash contains higher silica and alumina. The coarse material which is black in color may be the unburnt or partially burnt coal particles.

Most fly ashes are reported to have three types of particles (76): clearglassy spheres, spongy particles and brown to dark glassy particles. The clear glassy spheres which consist of mainly silica and alumina have a density of 2.5 to $2.74 \mathrm{~g} / \mathrm{cc}$. The larger black spongy particles, usually irregular in shape, are coal particles and have a density of 1.3 to $1.6 \mathrm{~g} / \mathrm{cc}$ (39). The spherical and rounded light brown to black particles contain 50 to $95 \%$ of the total iron in fly ash and have a density of 3.6 to $4.8 \mathrm{~g} / \mathrm{cc}$ (34). A small portion of fly ash particles, floats when mixed. with water (54). This low-density, hollow-sphere material consists of particles called cenospheres. Cenospheres 
average 20 to 200 microns in diameter. The thickness of the shell is about $10 \%$ of the radius. The true particle density of the individual spheres is in the range of 0.4 to $0.6 \mathrm{~g} / \mathrm{cc}$, and the bulk density .25 to $.4 \mathrm{~g} / \mathrm{cc}$. The gas in the cenosphere consists of mainly $\mathrm{CO}_{2}$ and $\mathrm{N}_{2}$. Chemical composition of the cenosphere varies as follows: $\mathrm{SiO}_{2}, 55$ to $61 \%$; $\mathrm{Al}_{2} \mathrm{O}_{3}, 26$ to $30 \%$ and $\mathrm{Fe}_{2} \mathrm{O}_{3}, 4$ to $10 \%$ (54).

\section{Chemical composition}

More than $85 \%$ (10) of most fly ashes consists of alumina, silica, iron oxide, lime and magnesia, with the percentage of any one constituent varying over a wide range of values, depending on the character of the particular ash being analyzed. Capp and spencer (14) give the range and average of constituents in United States fly ashes, as shown in Figure 2 .

Silica and alumina, present in glassy form, are the major constituents in fly ash $(42,77)$. Kaolinite, $\mathrm{Al}_{2} \mathrm{O}_{3} \cdot 2 \mathrm{SiO}_{2} \cdot 2 \mathrm{H}_{2} \mathrm{O}(12,13)$ under the influence of temperature, transforms first to metakaolin and then further to a mullite phase, $3 \mathrm{Al}_{2} \mathrm{O}_{3} \cdot 2 \mathrm{SiO}_{2}$ at $500^{\circ} \mathrm{C}$. At $925^{\circ} \mathrm{C}$, a spinel-type of approximate composition $2 \mathrm{Al}_{2} \mathrm{O}_{3} \cdot 3 \mathrm{SiO}_{2}$ is formed. At 1,050 to $1,100^{\circ} \mathrm{C}$, the spinel type structure transforms to a mullite phase with elimination of silica, appearing as cristoballite. This reaction will continue till $1,400^{\circ} \mathrm{C}(12,13$, 


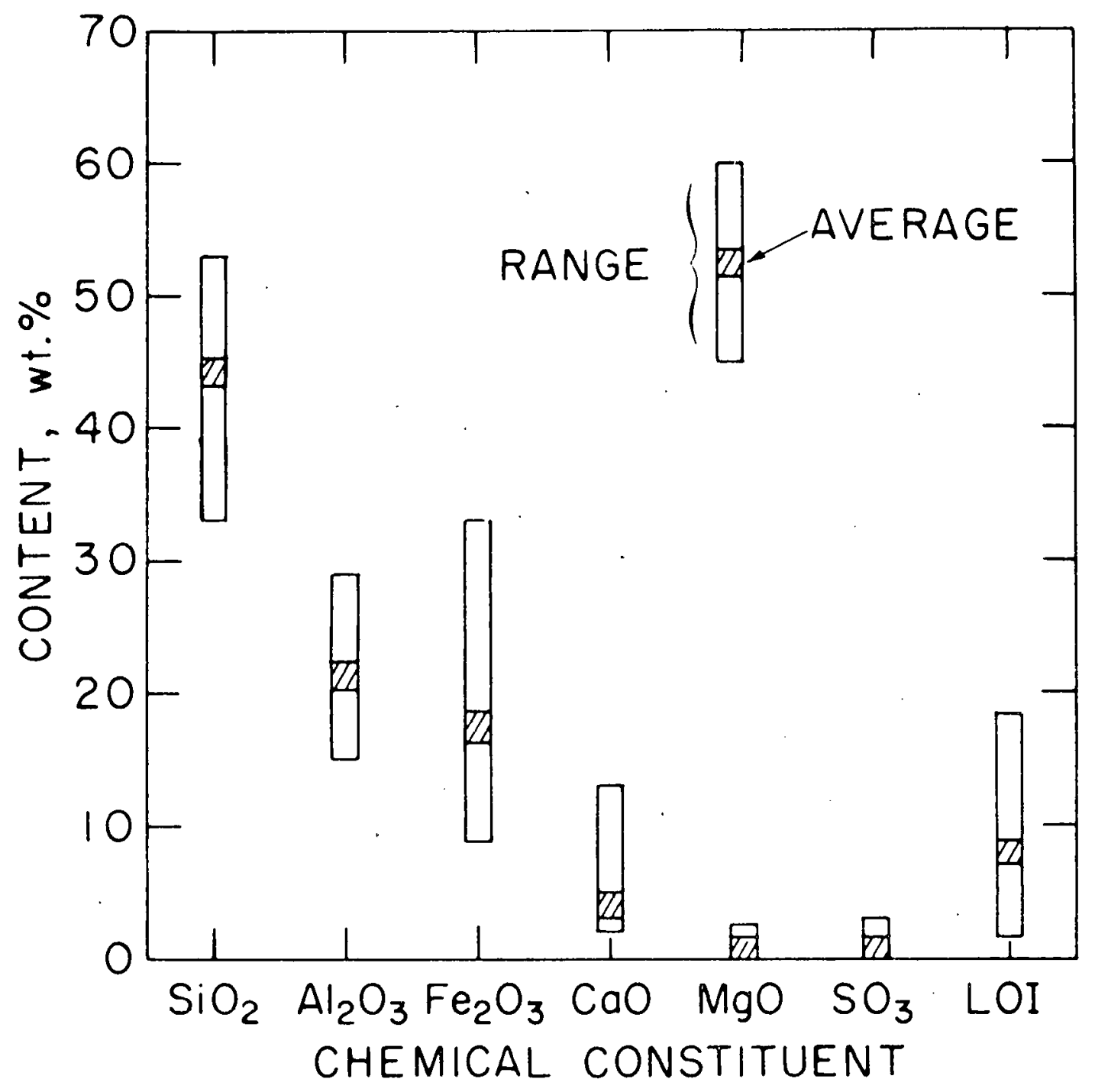

Figure 2. Range and average of analyses of United States fly ash (percent concentration by weight) (14) 
16). The presence of mullite, $3 \mathrm{Al}_{2} \mathrm{O}_{3} \cdot 2 \mathrm{SiO}_{2}$, in fly ash has been verified by $x$-ray diffraction studies $(34,42$, $76,77)$

Iron is found in fly ash in both glassy and crystalline forms. Hematite, $\alpha-\mathrm{Fe}_{2} \mathrm{O}_{3}$, and magnetite, $\mathrm{Fe}_{3} \mathrm{O}_{4}$, are present in crystalline form $(40,42,76,77)$. At $300^{\circ}$ to $500^{\circ} \mathrm{C}$, pyrite, $\mathrm{FeS}_{2}$, decomposes into Fes and $\mathrm{S}$; Fes in turn is oxidized to $\mathrm{Fe}_{2} \mathrm{O}_{3}$ and $\mathrm{Fe}_{3} \mathrm{O}_{4}(46,79)$.

United States fly ashes contain less calcium oxide and magnesium oxide than European fly ashes. This may be due to the fact that more lignite coals are used by European power plants $(30,34)$. A small quantity of sulfur trioxide, $\mathrm{SO}_{3}$, is also present $(14,34)$. Carbon, the unburnt coal, constitutes from 1 to $20 \%$ of the total weight, depending upon the type of coal and power plant conditions (14).

Utilization of and Current Research on Fly Ash in the United States

Capp and spencer (14), have made a detailed survey of the major uses of fly ash in the United States. Utilization of fly ash in the concrete and cement industries constitutes the largest single market. About two million tons is used annually (25). Fly ash is valuable in cement and concrete manufacture because it is a pozzolan. Pozzolans are siliceous or siliceous-alumineous materials that, in finely divided 
form and in the presence of moisture, are able to chemically react with calcium hydroxide or other alkaline earth hydroxide. to form compounds that possess cementious properties (14). Sintered fly ash is also used in manufacturing lightweight aggregates $(14,19)$. The fly ash is heated to about $1,250^{\circ} \mathrm{C}$, a temperature that softens and agglomerates the ash into pellets of some useful form. Aggregates made from fly ash can withstand pressure ranging from 1,000 to more than 4,000 psi. They also have the advantage over other types of aggregate in terms of insulation characteristics, resistance to firing and shrinkage upon drying (14). Limefly ash mixtures, or Poz-o-Pac by their trade name, are widely used for soil stabilization and road construction. Pavement with lime-fly ash stabilized soils now exists in more than 30 states, including Iowa (14).

Fly ash also plays an important role in brick manufacture and in agriculture. In agriculture, fly ash has been used in soil modification, land reclamation and other applications as cited by Capp and Spencer (14).

Slonaker and Leonard (67) have summarized current research in coal fly ash in the United States. At the Virginia Polytechnic and state university, fly ash is being tested as an agricultural fertilizer; the U.S. Bureau of Mines, Pittsburgh, Pennsylvania, has been successful in 
utilizing fly ash as an extinguisher in mine fire and subsidence control; at Notre Dame University and the Polytechnic Institute of New York, separate processes have been developed to remove phosphates from water with fly ash; recent interest has been focused on application of cenospheres. Being hollow; spherical and extremely lightweight, cenospheres have been used at Washington State University to develop "syntactic foam" to achieve buoyancy in deep ocean environment and at Grumman Aerospace Corporation to produce a closed pore insulation material for use on a space shuttle. Other numerous applications of cenospheres, such as providing fire-proofing and insulating materials for high-voltage electrical cables, have also been reported by slonaker and Leonard (67).

Recovery of Alumina from Bauxite

Bauxite is the major source of alumina and is believed to consist of a mixture of gibbsite $\left(\mathrm{Al}_{2} \mathrm{O}_{3} \cdot 3 \mathrm{H}_{2} \mathrm{O}\right)$ and diaspore $\left(\mathrm{Al}_{2} \mathrm{O}_{3} \cdot \mathrm{H}_{2} \mathrm{O}\right)$ with certain impurities (22). The impurities are essentially kaolinite $\left(\mathrm{Al}_{2} \mathrm{O}_{3} \cdot 2 \mathrm{SiO}_{2} \cdot 2 \mathrm{H}_{2} \mathrm{O}\right)$, halloysite (aqueous $\mathrm{Al}_{2} \mathrm{O}_{3} \cdot 2 \mathrm{SiO}_{2} \cdot 2 \mathrm{H}_{2} \mathrm{O}$ ), geothite ( $\alpha-$ FeO $(\mathrm{OH}))$, hematite $\left(\mathrm{Fe}_{2} \mathrm{O}_{3}\right)$, magnetite $\left(\mathrm{Fe}_{2} \mathrm{O}_{3} \cdot \mathrm{FeO}\right)$, anatase (tetragonal $\mathrm{TiO}_{2}$ ) and quartz $(15,22)$.

The Bayer process (22) is by far the most widely used 
method for the production of alumina. It, however, requires high-grade bauxite. In the Bayer process, the bauxite, ground to 80 to 100 mesh is digested with hot sodium hydroxide to form a solution of sodium aluminate, $\mathrm{NaAlO}_{2}$. The sodium aluminate solution is then seeded with hydrated alumina to form a precipitate of aluminum trihydrate. The aluminum trihydrate is washed to remove the soda and calcined at $1,000^{\circ} \mathrm{C}$ to produce pure alumina $(15,16,22)$. The iron oxide of the bauxite is insoluble in the sodium hydroxide solution and can be filtered off. The silica, on the other hand, causes serious losses of both soda and alumina. During digestion, "red mud", which contains insoluble sodium aluminum silicate, is formed. Seimiya (64) found that the "red mud" contains sodalite compounds, $3\left(\mathrm{Na}_{2} \mathrm{O}_{n} \mathrm{Al}_{2} \mathrm{O}_{3} \cdot 2 \mathrm{SiO}_{2}\right) \cdot \mathrm{Na}_{2} \mathrm{X} \cdot 2 \mathrm{H}_{2} \mathrm{O}$, where $X$ is an anion dependent upon the salt present in the solution. Titanium oxide is also found to form insoluble sodium titanates during digestion $(22,53)$. It is reported that for every pound of silica in the bauxite, 1 to 2 pounds of alumina and 1 to 3 pounds of sodium carbonate are lost (22).

Numerous alumina extraction processes from low-grade bauxite have been cited in the literature $(2,22,23)$. Basically, they may be broadly classified into two types (16): (a) wet processes in which the alumina is directly 
extracted by means of an aqueous agent, e.g., the alkaline (Bayer process) or acid extractions; (b) dry processes in which the essential step is furnacing with lime or soda to produce soluble sodium or calcium aluminate.

In general, iron causes no trouble in the alkaline process because ferric oxide is substantially insoluble in alkali solutions, but silica is always a problem, as in the Bayer process. Acid processes, as reported by Edwards, et al. (22) always dissolve the iron from the ore, but not the silica. Titanium is likely to be partly dissolved. The iron salts are so closely related to the alumina salts in their chemical behavior that a complete separation is expensive. The acid process usually involves the conversion of alumina compound in the ore into aluminum sulfates, chloride and nitrates (22).

Furnace processes (22) uses sodium carbonate and lime, Finely ground bauxite is uniformly mixed with powdered soda ash and sintered to form sodium aluminate. In the meantime, sodium ferrite, sodium titanate and sodium silicate are also formed. In the subsequent leaching step, the sodium ferrite reacts with water to form insoluble ferric hydroxide and sodium hydroxide, while silica is mostly precipitated as sodium aluminum silicate. The sodium aluminum silicate and sodium titanate represent real soda losses, and in addition, 
the silica may go into solution and contaminate the product $(16,22)$. Consequently, lime is added to form insoluble calcium salts with the impurities.

A practical process using only calcium carbonate is the Pederson process (22), in which a mixture of iron ore, coke, lime and bauxite is used to produce a molten calcium aluminate of low silica content. The alumina can be extracted by means of a sodium carbonate solution which forms insoluble calcium carbonate and soluble sodium aluminate (22).

Fly ash, however, contains a high percentage of both iron and silica. The average United States fly ash contains 30 to $50 \%$ silica and 9 to $38 \%$ iron by weight (14). In addition, much of the alumina is present in fly ash as mullite, a refractory aluminum silicate, and alumina-siliceous glasses (15), Chemically, they are different from hydrates of alumina, gibbsite and diaspore, which are present in bauxite. As a result, the conventional alumina recovery processes cannot be applied directly.

\section{Alumina Recovery from clay}

Clays which contain kaolinite, $\left(\mathrm{Al}_{2} \mathrm{O}_{3} \cdot 2 \mathrm{SiO}_{2} \cdot 2 \mathrm{H}_{2} \mathrm{O}\right)$, halloysite (aqueous $\mathrm{Al}_{2} \mathrm{O}_{3} \cdot 2 \mathrm{SiO}_{2} \cdot 2 \mathrm{H}_{2} \mathrm{O}$ ) and allophanite $\left(\mathrm{Al}_{2} \mathrm{O}_{3} \cdot \mathrm{SiO}_{2} \cdot 5 \mathrm{H}_{2} \mathrm{O}\right)$, consist of 30 to $40 \%$ alumina compared to 608 alumina in bauxite (22). The United States Bureau of 
Mines has developed several different processes for recovering alumina from clays $(31,32,33,55,56,57,58,59,60,61)$. One of them, called the acid process, uses sulfuric, hydrochloric and nitric acid respectively to selectively dissolve the alumina. The sintering process uses lime or soda ash to mix with the clays to form aluminates which are then leached by dilute alkali solutions to separate the alumina. Two other processes, the ammonium alum and the potassium alum processes, have also been reported by the Bureau of Mines (58, 59). Some private enterprises also have reported their newly developed processes. Among others, Applied Aluminum Research Corporation announced its Toth process which involves a chlorination step, and Pechiney Aluminum its H-plus process which uses both sulfuric acid and hydrochloric acid and claims to be superior to the traditional Bayer process $(47,63)$.

\section{Acid processes}

Acid processes, according to Edwards et al. (22) always dissolve more or less of the iron in clays but not the silica. As a result, acid processes generally are best adapted to treating ores low in iron. Before the extraction step, some preliminary treatments of the clays are essential (72). These include grinding and roasting. A particle size of 80 to 200 mesh is necessary to ensure acid penetration 
during extraction. The rate of extraction of alumina is increased if the clay has been roasted at $500^{\circ}$ to $900^{\circ} \mathrm{C}$ $(16,72)$

Sulfuric acid process In the sulfuric acid process, no insoluble compounds containing silica and alumina as a sulfate are formed which would cause alumina losses as in the Bayer process. However, iron does dissolve and must be separated because any iron oxide in the alumina product will be reduced during alumina reduction and contaminate the final product (57).

In the process, the raw clay is ground and then dehydrated in kilns operating at $700^{\circ} \mathrm{C}$. Tilley et al. (72) investigated the effect of acid strength on extractability of alumina and discerned that maximum alumina extraction occurred when acid strengths were between 30 and $50 \%$. Above 50\%, extractability decreased significantly. Walthall, et al. (75) found that the rate of alumina extraction became diffusion controlled at higher acid concentrations. The. resulting increased acid viscosity increased the resistance to diffusion and hence slowed the extraction rate.

Peters et al. (57) reported several sulfuric processes, similar in many aspects but each with its own method of separating the iron from the alumina product. In all the proposed processes, calcined clays were first leached with 
$40 \%$ sulfuric acid according to the following reaction:

$$
\mathrm{Al}_{2} \mathrm{O}_{3} \cdot 2 \mathrm{SiO}_{2}+3 \mathrm{H}_{2} \mathrm{SO}_{4}+\mathrm{Al}_{2}\left(\mathrm{SO}_{4}\right)_{3}+2 \mathrm{SiO}_{2}+3 \mathrm{H}_{2} \mathrm{O} \text {. }
$$

The aluminum sulfate was then calcined at $1300^{\circ} \mathrm{C}$ to form alumina. This reaction may be represented by the Equation $(57):$

$$
\mathrm{Al}_{2}\left(\mathrm{SO}_{4}\right)_{3} \stackrel{1,300^{\circ} \mathrm{C}}{\longrightarrow} \mathrm{Al}_{2} \mathrm{O}_{3}+2 \mathrm{SO}_{2}+\mathrm{SO}_{3}+\mathrm{O}_{2}
$$

Hydrochloric acid process Compared with the sulfuric acid process, the hydrochloric acid process is more expensive (16), but has advantages over the other acid processes in case of filtration of slurries and the removal of iron (56). The extraction of alumina by hydrochloric acid is carried out at about $95^{\circ} \mathrm{C}$ under atmospheric pressure with $20 \%$ hydrochloric acid. The leaching step may be expressed by the reaction (56):

$$
\mathrm{Al}_{2} \mathrm{O}_{3} \cdot 2 \mathrm{SiO}_{2}+6 \mathrm{HCl}+2 \mathrm{AlCl}_{3}+2 \mathrm{SiO}_{2}+3 \mathrm{H}_{2} \mathrm{O}
$$

The resulting solution contains aluminum chloride, iron chloride and insoluble silica. Peters et al. (56) evaluated five different methods for removing the iron from the aluminum chloride. After all the impurities have been removed, the aluminum chloride is calcined at about $1,100^{\circ} \mathrm{C}$ to produce alumina according to the reaction (56):

$$
2\left(\mathrm{AlCl}_{3} \cdot 6 \mathrm{H}_{2} \mathrm{O}\right) \rightarrow \mathrm{Al}_{2} \mathrm{O}_{3}+6 \mathrm{HCl}+9 \mathrm{H}_{2} \mathrm{O}
$$


Nitric acid process Like the hydrochloric acid process, nitric acid process is more expensive than the sulfuric acid process. However, nitric acid dissolves less iron than the other two acids. Another advantage of using nitric acid is the low temperature at which aluminum nitrate crýstals can be decomposed as compared with the higher temperatures required by the other acid processes (32).

Work has been cited by Johnson et al. (32) in which $30 \%$ nitric acid was used to digest calcined clays at $165^{\circ} \mathrm{C}$ and 6 atmospheres. The reaction is:

$$
\mathrm{Al}_{2} \mathrm{O}_{3} \cdot 2 \mathrm{SiO}_{2}+6 \mathrm{HNO}_{3} \rightarrow 2 \mathrm{Al}\left(\mathrm{NO}_{3}\right)_{3}+2 \mathrm{SiO}_{2}+3 \mathrm{H}_{2} \mathrm{O}
$$

The aluminum nitrate can be converted to alumina and oxides of nitrogen by heating at above $300^{\circ} \mathrm{C}$.

\section{Ammonium a lum process}

Peters et al. (59) describes two ammonium alum processes, leaching and baking, in which ammonium alum is crystallized for product purification. In the leaching process, the calcined clay is leached with an $85 \%$ ammonium bisulfate and $15 \%$ ammonium sulfate solution at $40^{\circ} \mathrm{C}$ and atmospheric pressure. The alumina is dissolved according to the following reaction (59):

$$
\mathrm{Al}_{2} \mathrm{O}_{3}+6 \mathrm{NH}_{4} \mathrm{HSO}_{4}+\mathrm{Al}_{2}\left(\mathrm{SO}_{4}\right)_{3}+3\left(\mathrm{NH}_{4}\right)_{2} \mathrm{SO}_{4}+3 \mathrm{H}_{2} \mathrm{O}
$$


In the baking process, the calcined clay is baked with ammonium sulfate at $400^{\circ} \mathrm{C}$. The principal reaction can be expressed as follows (59):

$$
\begin{aligned}
\mathrm{Al}_{2} \mathrm{O}_{3} \cdot 2 \mathrm{SiO}_{2} \cdot 2 \mathrm{H}_{2} \mathrm{O} & +4\left(\mathrm{NH}_{4}\right)_{2} \mathrm{SO}_{4} \rightarrow \mathrm{Al}_{2}\left(\mathrm{SO}_{4}\right)_{3} \cdot\left(\mathrm{NH}_{4}\right)_{2} \cdot \mathrm{SO}_{4} \\
& +2 \mathrm{SiO}_{2}+6 \mathrm{NH}_{3}+5 \mathrm{H}_{2} \mathrm{O}
\end{aligned}
$$

The aluminum sulfate is then calcined to product alumina. Reports have shown that 80 to $98 \%$ of the alumina can be recovered by this process $(26,59)$.

\section{Potassium alum process}

In this process, the calcined clay is leached countercurrently with a solution containing sulfuric acid and potassium sulfate. Alumina is dissolved as potassium alum which is then purified by crystallizing the alum from the solution. The alum is next decomposed in autoclaves to alumina potassium sulfate and sulfur dioxide. The principal reactions may be represented as follows (58):

$$
\begin{aligned}
& \mathrm{Al}_{2} \mathrm{O}_{3} \cdot 2 \mathrm{SiO}_{2}+3 \mathrm{H}_{2} \mathrm{SO}_{4}+\mathrm{K}_{2} \mathrm{SO}_{4}+21 \mathrm{H}_{2} \mathrm{O} \rightarrow \\
& \mathrm{K}_{2} \mathrm{SO}_{4} \cdot \mathrm{Al}_{2} \mathrm{O}_{3} \cdot 3 \mathrm{SO}_{3} \cdot 24 \mathrm{H}_{2} \mathrm{O}+2 \mathrm{SiO}_{2} \\
& 3\left(\mathrm{~K}_{2} \mathrm{SO}_{4} \cdot \mathrm{Al}_{2} \mathrm{O}_{3} \cdot 3 \mathrm{SO}_{3} \cdot 24 \mathrm{H}_{2} \mathrm{O}\right) \rightarrow \mathrm{K}_{2} \mathrm{SO}_{4} \cdot 3 \mathrm{Al}_{2} \mathrm{O}_{3} \cdot 4 \mathrm{SO}_{3} \cdot 9 \mathrm{H}_{2} \mathrm{O} \\
& +5 \mathrm{H}_{2} \mathrm{SO}_{4}+2 \mathrm{~K}_{2} \mathrm{SO}_{4}+58 \mathrm{H}_{2} \mathrm{O} \\
& \mathrm{K}_{2} \mathrm{SO}_{4} \cdot 3 \mathrm{Al}_{2} \mathrm{O}_{3} \cdot 4 \mathrm{SO}_{3} \cdot 9 \mathrm{H}_{2} \mathrm{O} \rightarrow \mathrm{K}_{2} \mathrm{SO}_{4}+3 \mathrm{Al}_{2} \mathrm{O}_{3}+4 \mathrm{SO}_{3}+9 \mathrm{H}_{2} \mathrm{O}
\end{aligned}
$$




\section{Sintering process}

The sintering process in general is categorized into two groups with reference to materials added for fixation of the silica and the alumina in clays. In the first group, called the lime-sinter process, limestone and clay are mixed together and sintered to form calcium aluminate from which alumina is later extracted as sodium aluminate by leaching with a dilute solution of sodium carbonate. In the second group, called the lime-soda sinter process, soda ash besides limestone is added to form sodium aluminate before the leaching step $(31,60)$.

For either group, a complete sintering process includes several steps: (a) grinding and mixing of raw materials; (b) furnacing; (c) leaching; (d) desilication; (e) carbonation and (f) calcination $(16,31,60)$. Intimate mixing of the raw materials is essential. The raw materials are generally ground to minus 20 mesh. Mixing can be carried out in either a dry or wet state. Archibald and Nicholson (4) found that wet mixing gave better alumina recovery.

In the lime-soda sinter process, the raw mix usually contains 1 mole of soda ash per mole of alumina and 2 moles of calcium oxide per mole of silica. At $1,400^{\circ} \mathrm{C}$, the following reaction occurs $(31,60)$ : 


$$
\begin{aligned}
& \mathrm{Al}_{2} \mathrm{O}_{3} \cdot 2 \mathrm{SiO}_{2} \cdot 2 \mathrm{H}_{2} \mathrm{O}+4 \mathrm{CaCO}_{3}+\mathrm{Na}_{2} \mathrm{CO}_{3} \rightarrow \\
& \mathrm{Na}_{2} \mathrm{O} \cdot \mathrm{Al}_{2} \mathrm{O}_{3}+2\left(2 \mathrm{CaO} \cdot \mathrm{SiO}_{2}\right)+5 \mathrm{CO}_{2}+2 \mathrm{H}_{2} \mathrm{O}
\end{aligned}
$$

The sintered product is then leached at $60^{\circ} \mathrm{C}$ with dilute sodium carbonate solution to dissolve most of the sodium aluminate. However, some silica is believed to dissolve in the solution so a desilication step is needed to precipitate the silica in the form of $2 \mathrm{Na}_{2} \mathrm{O} \cdot \mathrm{Al}_{2} \mathrm{O}_{3} \cdot 3 \mathrm{SiO}_{2} \cdot 5 \mathrm{H}_{2} \mathrm{O}$. This is done by heating the solution at $180^{\circ} \mathrm{C}$ and 7 atmospheric pressures (33). The desilicated solution is then carbonated at $90^{\circ} \mathrm{C}$ to form alumina trihydrate as follows:

$$
\mathrm{Na}_{2} \mathrm{O} \cdot \mathrm{Al}_{2} \mathrm{O}_{3}+\mathrm{CO}_{2}+3 \mathrm{H}_{2} \mathrm{O} \rightarrow \mathrm{Al}_{2} \mathrm{O}_{3} \cdot 3 \mathrm{H}_{2} \mathrm{O}+\mathrm{Na}_{2} \mathrm{CO}_{3}
$$

The trihydrate is finally calcined at $1,100^{\circ} \mathrm{C}$ to produce $\alpha$-alumina $(31,60)$.

In the lime-sinter process, 1.6 moles of lime per mole of alumina and 2 moles of lime per mole of silica are required in the raw mixed. The reaction may be represented as follows $(31,60)$ :

$$
\begin{aligned}
& 3\left(\mathrm{Al}_{2} \mathrm{O}_{3} \cdot 2 \mathrm{SiO}_{2} \cdot 2 \mathrm{H}_{2} \mathrm{O}\right)+17 \mathrm{CaCO}_{3} \rightarrow 5 \mathrm{CaO} \cdot 3 \mathrm{Al}_{2} \mathrm{O}_{3} \\
& +6\left(2 \mathrm{CaO} \cdot \mathrm{SiO}_{2}\right)+17 \mathrm{CO}_{2}+6 \mathrm{H}_{2} \mathrm{O}
\end{aligned}
$$

The sintering, leaching, desilication, carbonation and calcination are the same as in the lime-soda sinter process. 


\section{Toth process}

This process was developed at the Applied Aluminum Research Corporation (New orleans) and named after its inventor, Charles Toth (47). In this process, the calcined clay is chlorinated in the presence of a reductant such as coke at $300^{\circ}$ to $1,000^{\circ} \mathrm{C}$. Chlorides of aluminum, iron, silicon and other metals are formed. 'In subsequent steps, fractional condensation separates the metal chlorides. The next step involves the reaction of aluminum chloride with manganese metal to produce aluminum metal and manganese chloride. The reduction reaction of the aluminum chloride can be represented as follows:

$$
\mathrm{AlCl}_{3}+3 \mathrm{Mn} \rightarrow 2 \mathrm{Al}+3 \mathrm{MnCl}_{2}
$$

The manganese chloride is then processed to recover and recycle manganese metal and chlorine $(6,47)$.

\section{H-plus process}

This relatively new aluminum recovery process is a result of a joint venture between Francis Pechiney-UgineKuhlmann and the Aluminum Company of Canada $(1,63)$. The goal of the process is to develop an alternative for the first stage of the traditional aluminum manufacture, the Bayer process, which separates alumina from bauxite ores. The Bayer process does this through selective solution of alumina 
with caustic soda. The H-plus process aims to separate alumina from a variety of much lower-grade ores through selective dissolution with sulfuric acid and purification with hydrochloric acid $(63,75)$. Sulfuric acid can dissolve the alumina to form aluminum sulfate without prior calcining or attack under pressure. Hydrochloric acid is then introduced into the sulfate solution to form crystallized hexahydrated aluminum chloride which upon heating produces anhydrous alumina of very high purity $(63,85)$.

\section{Iron and Alumina Recovery from Fly Ash}

The discussion thus far has been primarily on alumina recovery processes for clays and other highly silicaaluminous materials. Fly ash, however, contains both iron and alumina present in forms different from those in other alumina bearing materials, such as bauxite or clays. The intent of the discussion thus far has been to provide some fundamental knowledge of known alumina recovery schemes that might be applicable to fly ash processing.

\section{Magnetic separation of the iron}

Fly ash contains iron not only in ferroginous glasses but also as crystalline hematite and magnetite (15). Being highly magnetic in nature $(9,14,34,42,43,50,76)$, the iron in fly ash can be removed by magnetic separation. 
Minnik (43) describes a magnetic separator that produces a unique, rotating magnetic field imparting a choatic and random motion of the magnetic and nonmagnetic particles. The random motion of the particles places them in an expanded state relative to each other, effectively filtering out the magnetic iron-rich particles from the irondeficient particles.

Boux (9) uses a permanent magnetic arum separator to extract iron from coarse fly ash and reports that $65 \%$ of the iron is concentrated in the magnetically separated particles. chou (16) uses both wet and dry magnetic separations and is able to recover 70 to $90 \%$ of the iron from fly ash.

Sintering and acid processes for alumina recovery from fly ash

Nowak (50) describes two methods, sintering and sulfuric acid processing, for recovering alumina from power plant fly ash in Poland. Klemm (36) has also reported some early work to extract alumina from fly ash by dissolution in sulfuric acid: The solubilization of the alumina was low, varying from $5 \%$ in cold $98 \% \mathrm{H}_{2} \mathrm{SO}_{4}$ to about $15 \%$ in $30 \%$ $\mathrm{H}_{2} \mathrm{SO}_{4}$ solutions after boiling for a half hour. For the lime-sinter or Pederson process, Klemm (36) states that sufficient calcium oxide is needed to act as an agent which 
has a stronger affinity for silica than does alumina. The ratio of CaO to $\mathrm{SiO}_{2}$ must be 2 to 1 and that of $\mathrm{CaO}$ to $\mathrm{Al}_{2} \mathrm{O}_{3}$ 5 to 3 . Chou (16) has reported that at a sintering temperature of $1,380^{\circ} \mathrm{C}$ and a sintering time of 1.5 hours, he was able to recover $52 \%$ of the alumina from fly ash.

Klemm (36) further suggests two other processes that may also work for fly ash. One of them is a hydrochemical process which is essentially the Bayer process. In this process, concentrated sodium hydroxide solutions (100 to 200 $g \mathrm{NaOH} / \mathrm{litre}$ ) are used to extract the alumina hydrate $\left(\mathrm{Al}_{2} \mathrm{O}_{3} \cdot 3 \mathrm{H}_{2} \mathrm{O}\right.$ or $\left.\mathrm{Al}_{2} \mathrm{O}_{3} \cdot \mathrm{H}_{2} \mathrm{O}\right)$ from the ash as sodium aluminate. The other one is a high temperature chlorination process which selectively chlorinates iron, alumina, silica and other materials in the ash.

High Temperature Chlorination of Fly Ash

Nowak and Schuster $(48,49)$ describe a halide process for extraction of metallic oxides such as iron oxide from ores. They propose that iron oxide can be reduced by chlorination at $800^{\circ}$ to $1,200^{\circ} \mathrm{C}$ with carbon as the reducing agent. The exothermic reaction may be represented as:

$$
\mathrm{Fe}_{2} \mathrm{O}_{3}(\mathrm{~s})+3 \mathrm{C}(\mathrm{s})+3 \mathrm{Cl}_{2}(\mathrm{~g}) \rightarrow 2 \mathrm{FeCl}_{3}(\mathrm{~g})+3 \mathrm{CO}(\mathrm{g})
$$

Othmer and Nowak (51) give a new ordering of metals according to their activity or strength which depends on the 
affinity of a metal in an oxide to form its chloride. Table 1 (51) shows the order of a few of the important metals and mataloids at $800^{\circ}$ to $1,300^{\circ} \mathrm{C}$. The chloride-forming affinity of a metal at a given temperature is measured by the difference between the Gibbs free energy of its chlóride and its oxide. In a mixture of metallic oxides the metal of greatest affinity is the first to react with chlorine to form the chloride, provided the chlorine is present in only a limited amount. This resulting reaction allows one to separate readily metallic oxides from each other (51).

However, the combination of reduction and chlorination is so powerful that while the iron oxide is being chlorinated in quantitative measure, many of the other metallic oxides in the mixture are also chlorinated to some extent (48). In the nonmagnetic part of the fly ash, the major constituents are $\mathrm{SiO}_{2}, \mathrm{Al}_{2} \mathrm{O}_{3}$ and $\mathrm{Fe}_{2} \mathrm{O}_{3}$. The reduction-chlorination might involve three principal reactions:

$$
\begin{aligned}
& \mathrm{Fe}_{2} \mathrm{O}_{3}(\mathrm{~s})+3 \mathrm{C}(\mathrm{s})+3 \mathrm{Cl}_{2}(\mathrm{~g}) \rightarrow 2 \mathrm{FeCl}_{3}(\mathrm{~g})+3 \mathrm{CO}(\mathrm{g}) \\
& \mathrm{SiO}_{2}(\mathrm{~s})+2 \mathrm{C}(\mathrm{s})+2 \mathrm{Cl}_{2}(\mathrm{~g}) \rightarrow \mathrm{SiCl}_{4}(\mathrm{~g})+2 \mathrm{CO}(\mathrm{g}) \\
& \mathrm{Al}_{2} \mathrm{O}_{3}(\mathrm{~s})+3 \mathrm{C}(\mathrm{s})+3 \mathrm{Cl}_{2}(\mathrm{~g}) \rightarrow 2 \mathrm{AlCl}_{3}(\mathrm{~g})+3 \mathrm{CO}(\mathrm{g}) \\
& \text { According to de Beauchamp }(20) \text {, chlorine reacts in the } \\
& \text { presence of carbon with alumina appreciably at } 800^{\circ} \text { to } 900^{\circ} \mathrm{C} \text {, } \\
& \text { with iron oxide at } 200^{\circ} \mathrm{C} \text { and with silica at } 600^{\circ} \text { to } 800^{\circ} \mathrm{C} \text {. }
\end{aligned}
$$


Table 1. Chlorination order and boiling point of chlorides for some common elements (51)

\begin{tabular}{|c|c|c|c|c|}
\hline $\begin{array}{c}\text { Conventional } \\
\text { electrochemical } \\
\text { series } \\
\text { (highest at } \\
\text { bottom) }\end{array}$ & \multicolumn{2}{|c|}{$\begin{array}{l}\text { Chloride forming } \\
\text { affinity from oxide } \\
\text { (highest at top) }\end{array}$} & \multicolumn{2}{|c|}{$\begin{array}{c}\text { Atmospheric } \\
\text { Boiling point of } \\
\text { chlorides, } \\
{ }^{\circ} \mathrm{C}\end{array}$} \\
\hline $\mathrm{Cu}$ & $\mathrm{Cu}$ & $\mathrm{Pb}$ & $\mathrm{CuCl}$ & 1,690 \\
\hline $\mathrm{Pb}$ & $\mathrm{Pb}$ & $\mathrm{Cu}$ & $\mathrm{PbCl}_{2}$ & 954 \\
\hline $\mathrm{Sn}$ & $\mathrm{Zn}$ & $\mathrm{Zn}$ & $\mathrm{ZnCl}_{2}$ & 732 \\
\hline $\mathrm{Ni}$ & Co & Co & $\mathrm{CoCl}_{2}$ & 1,050 \\
\hline Co & $\mathrm{Ni}$ & $\mathrm{Sn}$ & $\mathrm{NiCl}_{2}$ & 973 \\
\hline $\mathrm{Fe}$ & $S n$ & $\mathrm{Ni}$ & $\mathrm{SnCl}_{4}$ & 114 \\
\hline$S$ & $\mathrm{Fe}$ & $\mathrm{Fe}$ & $\mathrm{FeCl}_{3}$ & 319 \\
\hline V & $\mathrm{Ti}$ & $\mathrm{Ti}$ & $\mathrm{TiCl}_{4}$ & 136 \\
\hline $\mathrm{Ti}$ & $\mathrm{Ge}$ & $\mathrm{Ge}$ & $\mathrm{GeCl}_{4}$ & 84 \\
\hline \multirow[t]{5}{*}{ Al } & $\mathrm{Al}$ & Al & $\mathrm{AlCl}_{3}$ & 183 \\
\hline & $\mathrm{Si}$ & $S i$ & $\mathrm{SiCl}_{4}$ & 58 \\
\hline & $\mathrm{V}$ & $S$ & & \\
\hline & P & $\mathrm{V}$ & & \\
\hline & $\mathbf{S}$ & $\mathrm{P}$ & & \\
\hline
\end{tabular}


Without carbon, the chlorination occurs at $1,200^{\circ} \mathrm{C}$ for alumina, $600^{\circ} \mathrm{C}$ for iron oxide and $1,200^{\circ} \mathrm{C}$ for silica. Since the boiling points of silicon, iron and aluminum chlorides vary widely, as shown in Table 1 , it appears possible, at first glance, to separate the chlorides by fractional condensation of the gaseous product (51). de Beauchamp (20) and Edwards et al. (22) however, state that while $\mathrm{SiCl}_{4}$ is readily separated from the product, it is very difficult to separate $\mathrm{FeCl}_{3}$ from $\mathrm{AlCl}_{3}$ for, although $\mathrm{AlCl}_{3}$ sublimes below the boiling point of $\mathrm{FeCl}_{3}\left(319^{\circ} \mathrm{C}\right), \mathrm{FeCl}_{3}$ is volatile enough at the sublimation temperature of $\mathrm{AlCl}_{3}$ $\left(183^{\circ} \mathrm{C}\right)$ that appreciable amounts of $\mathrm{FeCl}_{3}$ sublime with the $\mathrm{AlCl}_{3}$. Landsberg (37) has reported that under reducing conditions, a substantial loss of alumina accompanies the initial rapid iron chlorination at $500^{\circ} \mathrm{C}$. Accordingly, in order to produce aluminum chloride sufficiently pure to be used in an electrolytic cell, the impurities, especially iron chloride, have to be removed.

Peters et al. (56) describes five different ways of extracting iron from aluminum chloride. Eisele et al. (24) introduces an amine extraction method in which iron is reduced to less than $0.001 \%$ by weight, whereas the commercial impurity level for iron is 0.048 by weight (35).

Good et al. (29), Singleton et al. (66) and Kirby et al. 
investigated the electrochemical reduction of $\mathrm{AlCl}_{3}$ as a process for producing aluminum. Kirby et al. (35) used an externally heated, single-compartment cell with a rammed refractory lining and molten $\mathrm{KCl}-\mathrm{NaCl}-\mathrm{AlCl}_{3}$ as an electrolyte. They observed several advantages for the production of aluminum from $\mathrm{AlCl}_{3}$, rather than from $\mathrm{Al}_{2} \mathrm{O}_{3}$, in a fluoride system. For example, a lower operating temperature, $700^{\circ}$ to $750^{\circ} \mathrm{C}$ versus $960^{\circ}$ to $1,000^{\circ} \mathrm{C}$ in a Hall-Heroult cell, is needed and hence energy requirements are less. In addition, the $\mathrm{AlCl}_{3}$ cell utilizes a closed system and should minimize pollution problems such as are encountered in the HallHeroult Cell (35).

Based on this literature review, an experimental investigation of iron and aluminum recovery from a particular power plant fly ash by chlorination was undertaken. The study is intended to demonstrate that fly ash can be a potential source of aluminum, iron and possibly silicon. 


\section{EXPERIMENTAL PROCEDURE}

A sample of fly ash from the Lakeside Power Plant in Milwaukee, Wisconsin was used for this research work. For convenience, this ash is designated as c-l fly ash. Leonard (38) and Cavin (15) have provided the physical properties and chemical composition as well as other information on this sample.

\section{Material}

C-l fly ash was collected by mechanical precipitators from a dry bottom type boiler at the Lakeside Power Plant using coal from western Kentucky and southern Illinois. Leonard (38) gave some physical characteristics (Table 2). Cavin (15) in his thesis provided chemical composition for this $\mathrm{C}-1$ fly ash (Table 3).

Cavin (15) also provided information on determining other physical and chemical characteristics. By screening alone, Cavin (15) found that the majority of residual carbon in the ash could be removed. Water leaching the ash could also reduce the water soluble constituents, primarily CaO, Mgo and possibly $\mathrm{SO}_{3}$ (16). Cavin (15) also investigated the possibility of separating iron magnetically from the ash. In most alumina recovery processes, iron presents a serious problem by contaminating the product. The removal of iron 
Table 2. Physical characteristics of fly ash sample C-1 (38)

\begin{tabular}{lcccc}
$\begin{array}{c}\text { Total } \\
\text { specific } \\
\text { gravity }\end{array}$ & $\begin{array}{l}\text { Ignited } \\
\text { specific } \\
\text { gravityb }\end{array}$ & $\begin{array}{c}\text { Percent } \\
\text { passing } \\
325 \text { sieve }\end{array}$ & $\begin{array}{c}\text { Mean } \\
\text { diameter, } \\
\text { microns }\end{array}$ & $\begin{array}{c}\text { specific surface } \\
\text { area } \\
\mathrm{cm}^{2} / \mathrm{gm}^{\mathrm{d}}\end{array}$ \\
\hline 2.42 & 2.55 & 81.0 & 31.0 & 3370 \\
\hline
\end{tabular}

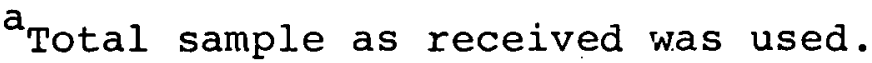

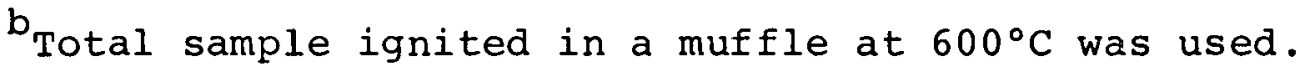

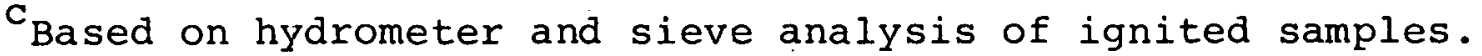

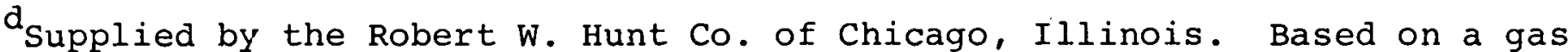
adsorption method, total sample used.

Table 3. Chemical composition of C-1 fly ash (15)

\begin{tabular}{llllllllll}
\hline \multicolumn{10}{c}{ Component (weight percent) } \\
\hline $\mathrm{SiO}_{2}$ & $\mathrm{Al}_{2} \mathrm{O}_{3}$ & $\mathrm{Fe}_{2} \mathrm{O}_{3}$ & $\mathrm{CaO}$ & $\mathrm{MgO}$ & $\mathrm{SO}_{3}$ & $\mathrm{C}$ & Other & L.O.D. & L.O.I.b \\
\hline 42.36 & 17.63 & 19.29 & 4.73 & 0.62 & 1.54 & 8.37 & 4.88 & 0.58 & 10.39 \\
\hline
\end{tabular}

${ }^{\mathrm{L} . O . D}$. is loss on drying to $110^{\circ} \mathrm{C}$.

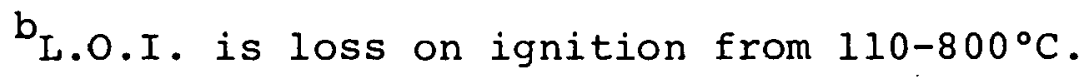


will serve as a first step towards recovering aluminum from fly ash by high temperature chlorination.

\section{Magnetic Separation}

In view of the uniform distribution of magnetics in various size fractions (15), magnetic separation was done on the whole $\mathrm{C}-1 \mathrm{fly}$ ash instead of on any particular fraction of the ash.

A laboratory-size moving field electromagnetic device built at the Ames Laboratory, Ames, Iowa, was used to separate the high-iron content magnetic fraction. The unit is shown in Figure 3. Minnick (43) described a similar alternating-current magnetic separator applicable to very fine fly ash. Dry C-l fly ash was fed by a vibrator to the magnetic field. Ferromagnetic particles were drawn to the magnetic surface. Due to the travelling magnetic field which develops a spinning motion, the ferromagnetic particles moved along the surface and collected in a highly turbulent "cloud". They then collided with one another and fell off from the magnetic field. Figure 4 shows the separation of magnetic and nonmagnetic particles. The nonmagnetic particles remained in the vibrator tray and fell off the end of the tray. Both fractions were collected in glass containers. The nonmagnetic fraction was passed through the separator 
Figure 3. Electromagnetic device used to separate ferromagnetic particles from coal fly ash

Figure 4. View of magnetic surface showing magnetic particles on the surface and nonmagnetic ones falling 
THIS PAGE

\section{WAS INTENTIONALLY \\ LEFT BLANK}



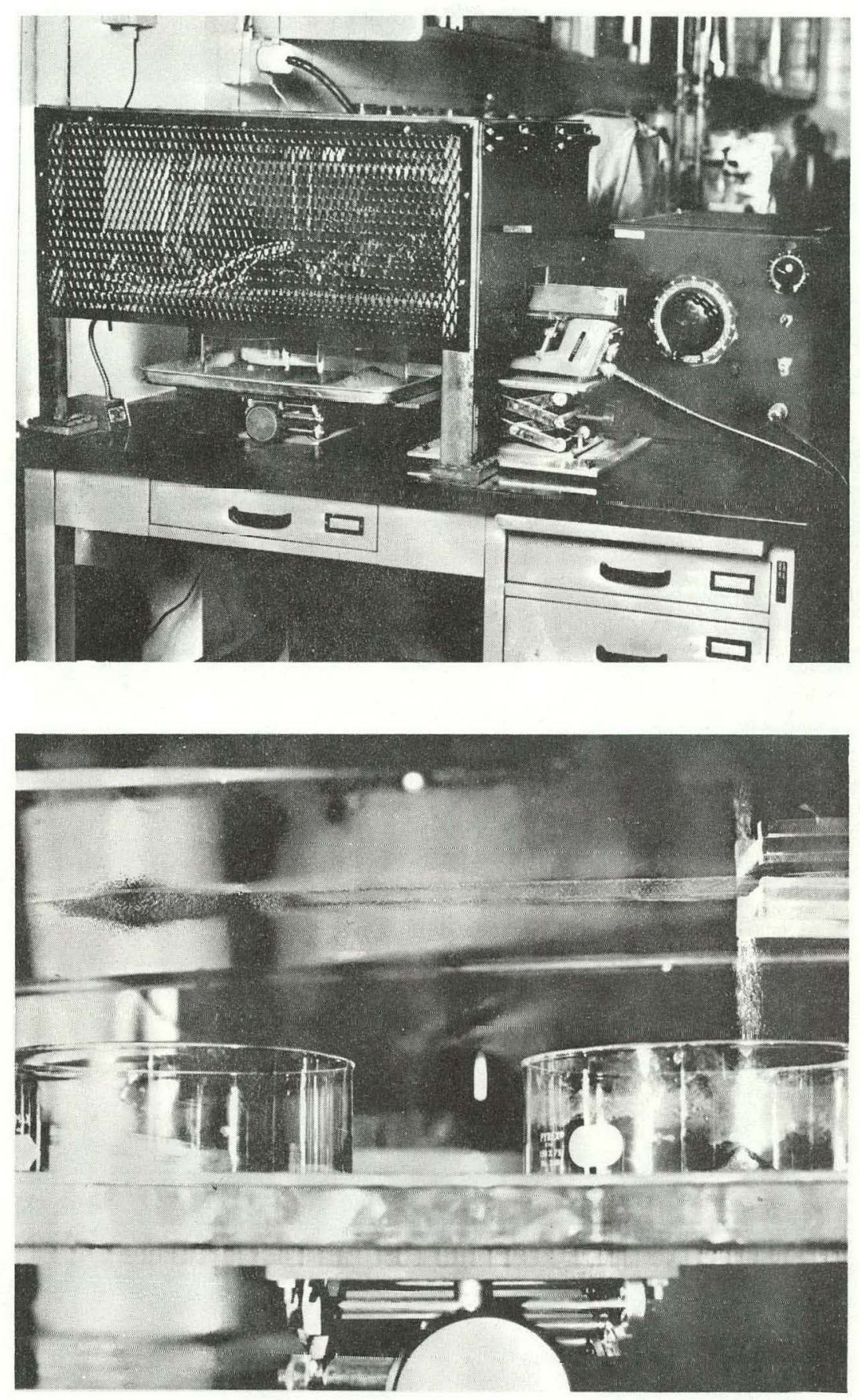
three times.

Quantitative Analysis

The magnetic and nonmagnetic portions of $\mathrm{C}-1$ fly ash were analyzed quantitatively for their oxide constituents, carbon content and loss on ignition. Techniques used in these analyses were described in the 1974 Annual Book of the American Society for Testing and Materials Standards (68). The sample to be analyzed is ashed under standard conditions and ignited to constant weight. Two solutions are then prepared. Solution I is obtained by fusing the ash with sodium hydroxide. The fused melt is dissolved in dilute hydrochloric acid. Solution II is made by decomposing the ash with sulfuric, hydrochloric and nitric acids.

Solution $\mathrm{I}$ is used for the analysis of $\mathrm{Al}_{2} \mathrm{O}_{3}$ and $\mathrm{SiO}_{2}$. Solution II is for the remaining constituents. Spectrophotometric procedures are used for determining $\mathrm{SiO}_{2}, \mathrm{Al}_{2} \mathrm{O}_{3}$, $\mathrm{Fe}_{2} \mathrm{O}_{3}, \mathrm{TiO}_{2}$ and $\mathrm{P}_{2} \mathrm{O}_{5}$; chelatrometric titration for $\mathrm{CaO}$ and MgO; flame photometry for $\mathrm{Na}_{2} \mathrm{O}$ and $\mathrm{K}_{2} \mathrm{O}(16,68)$.

\section{Preparation of Ash Samples}

The nonmagnetic fraction of the ash was mixed with carbon and ground in a ball mill for three hours to insure good mixing. The stoichiometric amount of carbon was mixed 
with the ash sample. The stoichiometric ash-to-carbon ratio is about 10 grams of nonmagnetic ash to 3 grams of carbon.

\section{High Temperature Chlorination}

The equipment for this experiment is as shown in Figure 5. All the connecting tubes and joints were made of glass. The reactor bed and the chloride condensation zone were made of Vycor. The preweighed ash sample, about 13 to 15 grams, was packed in the bed with small quartz pellets to improve porosity. An electric furnace, Type M-2018 from Hevi Duty Electric Co. was used. The temperature of the reactor bed was measured with a thermocouple and read on a chart recorder. Dry chlorine gas was passed through the bed at a controlled rate. A rotameter, Type 448-035 from LAB Crest Division, Fischer \& Porter Co. was used to control the chlorine flow: The chlorides, primarily iron, aluminum and silicon chlorides in gaseous forms, were gradually pushed out of the bed. Iron and aluminum chlorides, because of their high dew points, condensed at the condensation zone. The silicon chloride, however, was recovered by reaction with water. The silicon chloride was believed to react with water to form silicon oxide and hydrogen chloride. Carbon monoxide and carbon dioxide gases formed during the 


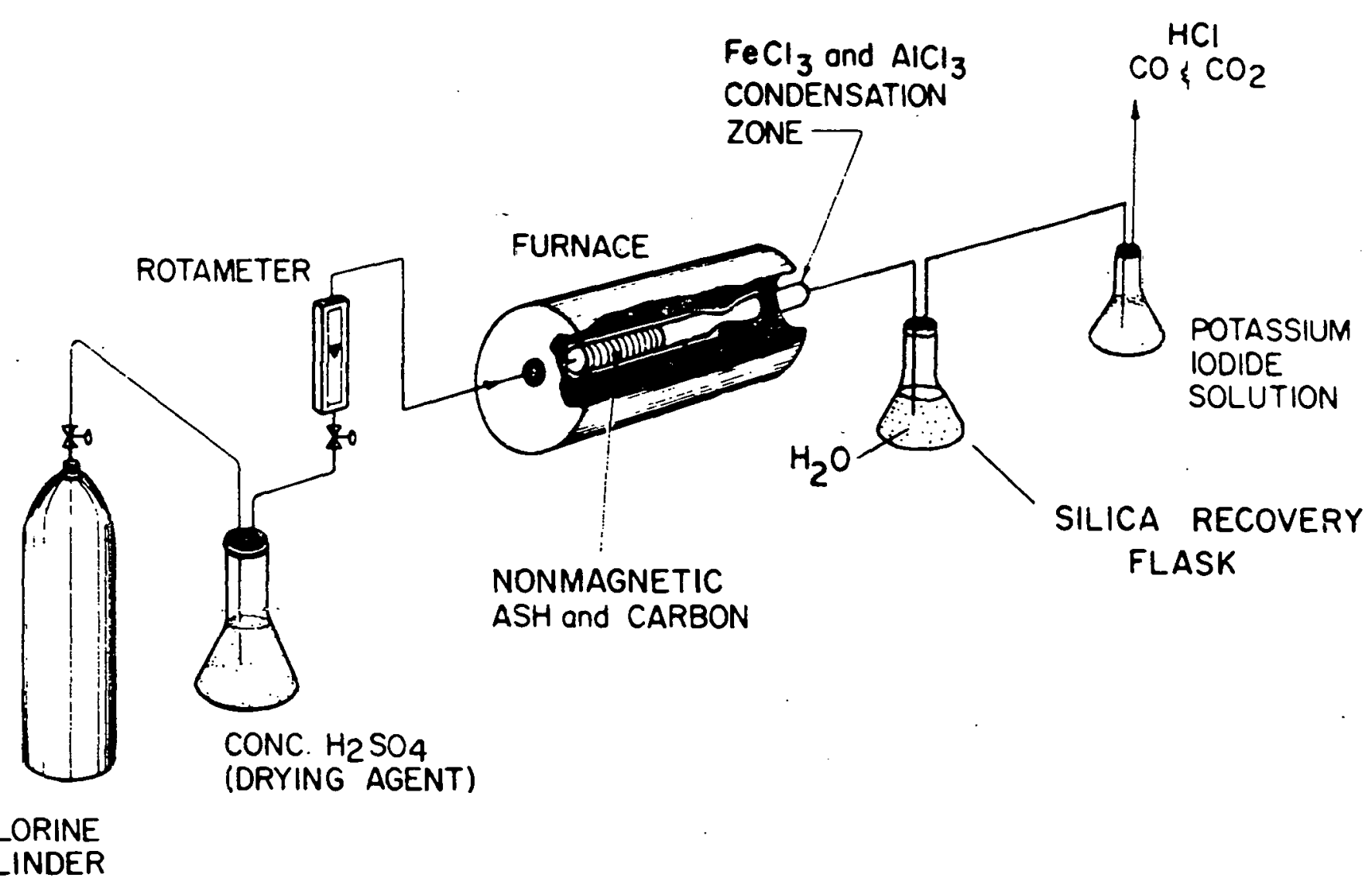

Figure 5. Equipment used in fly ash chlorination 
chorination reaction escaped to the atmosphere. KI solution was used to detect any chlorine gas in the exit gas. At the end of each run, the furnace was kept at temperature for an additional 30 minutes while the sample was being purged with argon gas in order to complete the volatilization of the chlorides produced.

Photomicroscopic Observations of Ash Samples

Both original and chlorinated $\mathrm{C}-1$ ash samples were dispersed in alcohol and treated with ultrasonic waves to prevent agglomeration. Photomicrographs were then taken with a Bausch and Lomb cameramicroscope.

\section{Analysis of the Chloride Products}

The chloride products were dissolved in water and the solution was analyzed for its iron and aluminum contents using standard gravimetric methods (74). The procedure is as follows:

Evaporate to dryness a sample solution at $120-130^{\circ} \mathrm{C}$ at least 1 hour to dehydrate the silica. Moisture the residue with $5 \mathrm{ml}$ of concentrated $\mathrm{HCl}$ and allow to stand at ambient temperature for 10 minutes. Add 100 $\mathrm{ml}$ of water and heat to boiling to dissolve soluble salts. Filter off the silicon oxide on an ashless filter paper. Wash the precipitate with warm $1 \mathrm{~N} \mathrm{HCl}$ and then with hot water until it is free of chlorides. The filtrate now contains $F e, A l$ and small amounts of $\mathrm{Ti}, \mathrm{Ca}$ and $\mathrm{Mg}$. To this filtrate, add a small amount of concentrated nitric acid and boil to oxidize the iron to the ferric state. Pour in excess of $2 \mathrm{~N} \mathrm{NaOH}$ solution until the $\mathrm{pH}$ reaches 12 . Heat the solution near boiling for 10-15 minutes. Filter off the $\mathrm{Fe}(\mathrm{OH})_{3}$ formed on an ashless filter paper. Wash the precipi- 
tate four times with $0.1 \mathrm{NaOH}$. The filtrate now contains $\mathrm{Al}$. To ensure the $\mathrm{Fe}(\mathrm{OH})_{3}$ precipitate is free of $\mathrm{Ca}$ and $\mathrm{Mg}$, dissolve it in $1 \mathrm{~N} \mathrm{HCl}$. Neutralize it with ammonium hydroxide to $\mathrm{pH}$ 5.5. Digest near boiling and filter off the $\mathrm{Fe}(\mathrm{OH})_{3}$. Neutralize the filtrate that contains $\mathrm{Al}$ with $\mathrm{HCl}$ to $\mathrm{pH}$ 5.9. Filter off the $\mathrm{Al}(\mathrm{OH})_{3}$ precipitate. The $\mathrm{Fe}(\mathrm{OH})_{3}$ and $\mathrm{Al}(\mathrm{OH})_{3}$ precipitates are washed with ammonium chloride solution and ignited in crucibles and weighed as $\mathrm{Fe}_{2} \mathrm{O}_{3}$ and $\mathrm{Al}_{2} \mathrm{O}_{3}$.

The aluminum and iron contents in the chloride products also were determined by a complexometric titration (62). This is a relatively simple and rapid method. The procedure is as follows:

Acidify the chloride solution and then add excess $0.05 \mathrm{M}$ CDTA $(1,2$ - diaminocyclohexane tetra-acetic acid). Bring $\mathrm{pH}$ to 5-5.5 with hexamethylenetetramine and add several drops of 0.58 xylenol orange. Titrate with $0.05 \mathrm{M}$ lead nitrate. The consumption of CDTA gives the sum of $\mathrm{Al}$ and $\mathrm{Fe}$. The amount of $\mathrm{Fe}$ can be determined as follows. To an aliquot of the solution add $1 \mathrm{M}$ ammonium fluoride $(0.5-0.8 \mathrm{ml}$ for $1 \mathrm{mg}$ of $\mathrm{Al})$. After 5 minutes add a measured volume of CDTA, adjust the $\mathrm{pH}$ to 5-5.5 again with hexamethylenetetramine and titrate with $0.05 \mathrm{M}$ lead nitrate. The consumption of CDTA gives the content of $\mathrm{Fe}$. The amount of $\mathrm{Al}$ can then be obtained by subtraction. 


\section{DISCUSSION OF RESULTS}

The exploratory experiments conducted in this research were intended to give some information on aluminum and iron recovery from power plant fly ash. Major work was focused on recovering alumina from fly ash by high temperature chlorination. Results of each experiment during this investigation are presented and discussed on the basis of observed experimental trends and direct experimental results.

\section{Results of Magnetic Separation}

Table 4 shows the chemical composition of both the magnetic and nonmagnetic fractions of $\mathrm{c}-1$ fly ash. After separation, about $25 \%$ of the iron oxide remained in the nonmagnetic fraction. This is due to the fact that iron occurs in fly ash as crystalline components, mainly magnetite and hematite, and as glass (65). A large part of the iron appears as magnetite. Being ferromagnetic, magnetite can be separated magnetically. Nevertheless, the intergrowth of some magnetite and hematite, a nonferromagnetic iron oxide, has resulted in the incomplete separation of the iron from the nonmagnetic fraction. Besides, the combination of some iron with alumina and silica in the glass has also made the complete separation difficult $(43,65)$. 
Table 4. Composition of $\mathrm{C}-1$ magnetic and nonmagnetic fractions

\begin{tabular}{|c|c|c|c|c|c|c|c|c|c|}
\hline \multirow{2}{*}{ Sample } & \multicolumn{8}{|c|}{ Component (weight percent) } & \multirow[b]{2}{*}{ L.O.I.a } \\
\hline & $\mathrm{SiO}_{2}$ & $\mathrm{Al}_{2} \mathrm{O}_{3}$ & $\mathrm{Fe}_{2} \mathrm{O}_{3}$ & $\mathrm{CaO}$ & $\mathrm{MgO}$ & $\mathrm{Na}_{2} \mathrm{O}$ & $\mathrm{K}_{2} \mathrm{O}$ & $\mathrm{SO}_{3}$ & \\
\hline $\begin{array}{l}\text { Whole fly ash } \\
\text { (100: by wt.) }\end{array}$ & 42.36 & 17.91 & 19.29 & 4.49 & 0.71 & 0.35 & 1.72 & 2.13 & 10.39 \\
\hline $\begin{array}{l}\text { Magnetic } \\
(22.0 \% \text { by wt.) }\end{array}$ & 12.32 & 6.75 & 76.82 & 1.44 & .26 & .10 & .43 & .74 & .68 \\
\hline $\begin{array}{l}\text { Nonmagnetic } \\
(75.5 \% \text { by wt.) }\end{array}$ & 46.95 & 18.84 & 6.64 & 5.36 & 1.49 & 0.37 & 1.73 & 2.28 & 11.54 \\
\hline
\end{tabular}

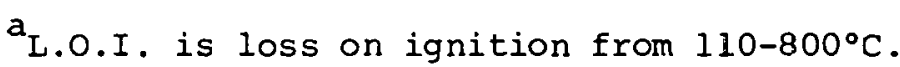


Results of Chlorinating the Iron Oxide at

Low Temperature

In the presence of carbon, chlorine reacts with iron oxide at about $200^{\circ} \mathrm{C}$; it reacts substantially with alumina at $600-800^{\circ} \mathrm{C}(20)$. An attempt was made to chlorinate the iron oxide in the ash without chlorinating the alumina. This step would serve to further separate the iron oxide from the nonmagnetic fly ash and hence reduce the degree "of iron contamination to the aluminum product.

Since ferric chloride has a boiling point of $319^{\circ} \mathrm{C}$ (20), a sample of the ash was first chlorinated at $550^{\circ} \mathrm{C}$ for 30 minutes. The temperature was then increased successively to $650^{\circ} \mathrm{C}, 750^{\circ} \mathrm{C}$ and $850^{\circ} \mathrm{C}$, each with a reaction time of 1 hour. The results are shown in Table 5 .

Table 5. Recovery of aluminum oxide and iron oxide by successive chlorination

\begin{tabular}{cccc}
\hline Temp. ${ }^{\circ} \mathrm{C}$ & $\begin{array}{r}\text { Reaction time, } \\
\text { hr. }\end{array}$ & $\begin{array}{c}\text { Aluminum oxide } \\
\text { wt. oga }\end{array}$ & $\begin{array}{c}\text { Iron oxide } \\
\text { wt. } 8 \text { o }\end{array}$ \\
\hline 550 & $1 / 2$ & 1.1 & 41.4 \\
650 & 1 & 38.9 & 36.8 \\
750 & 1 & 38.9 & 13.7 \\
850 & 1 & 23.4 & 14.9
\end{tabular}

ancremental percentage of amount present in the original. nonmagnetic ash fraction. 
Table 5 shows that at $550^{\circ} \mathrm{C}$ chlorine will attack primarily iron oxide, but very little alumina. More than $40 \%$ of the iron oxide can be separated from the ash with little loss of alumina. But as the temperature is increased, a substantial amount of alumina is chlorinated along with the iron oxide. This observation demonstrates the fact that $40 \%$ of the iron oxide in the nonmagnetic fraction occurs as a mixture of magnetite and hematite which remains exposed and reacts more readily with chlorine at $550^{\circ} \mathrm{C}$. The other 608 of the iron oxide probably agglomerates with alumina or silica, and possibly both. After the free "exposed" iron oxide has been chlorinated, a higher temperature is required to continue the reaction. This results in the alumina being chlorinated too.

\section{Results of Photomicroscopic Observations of Ash Samples}

Figures 6 and 7 show photomicrographs of both magnetic and nonmagnetic fractions respectively. In Figure 6, there are a lot of spherical and rounded particles which appear light brown to very dark in color. Deepening color suggests increasing iron content. In Figure 7, there are predominantly large giassy lumps of particles of irregular shapes. These large slightly colored particles consist of silica, alumina and possibly iron oxide in fused form. This 
Figure 6. Photomicrograph of the magnetic fraction of C-1 fly ash at loox. The deepening color of the particles suggests increasing iron content

Figure 7. Photomicrograph of the nonmagnetic fraction of C-l fly ash at loox. There are a lot of glassy particles which consist of the principal alumino-silicious material in the fly ash 


\section{THIS PAGE}

\section{WAS INTENTIONALLY \\ LEFT BLANK}



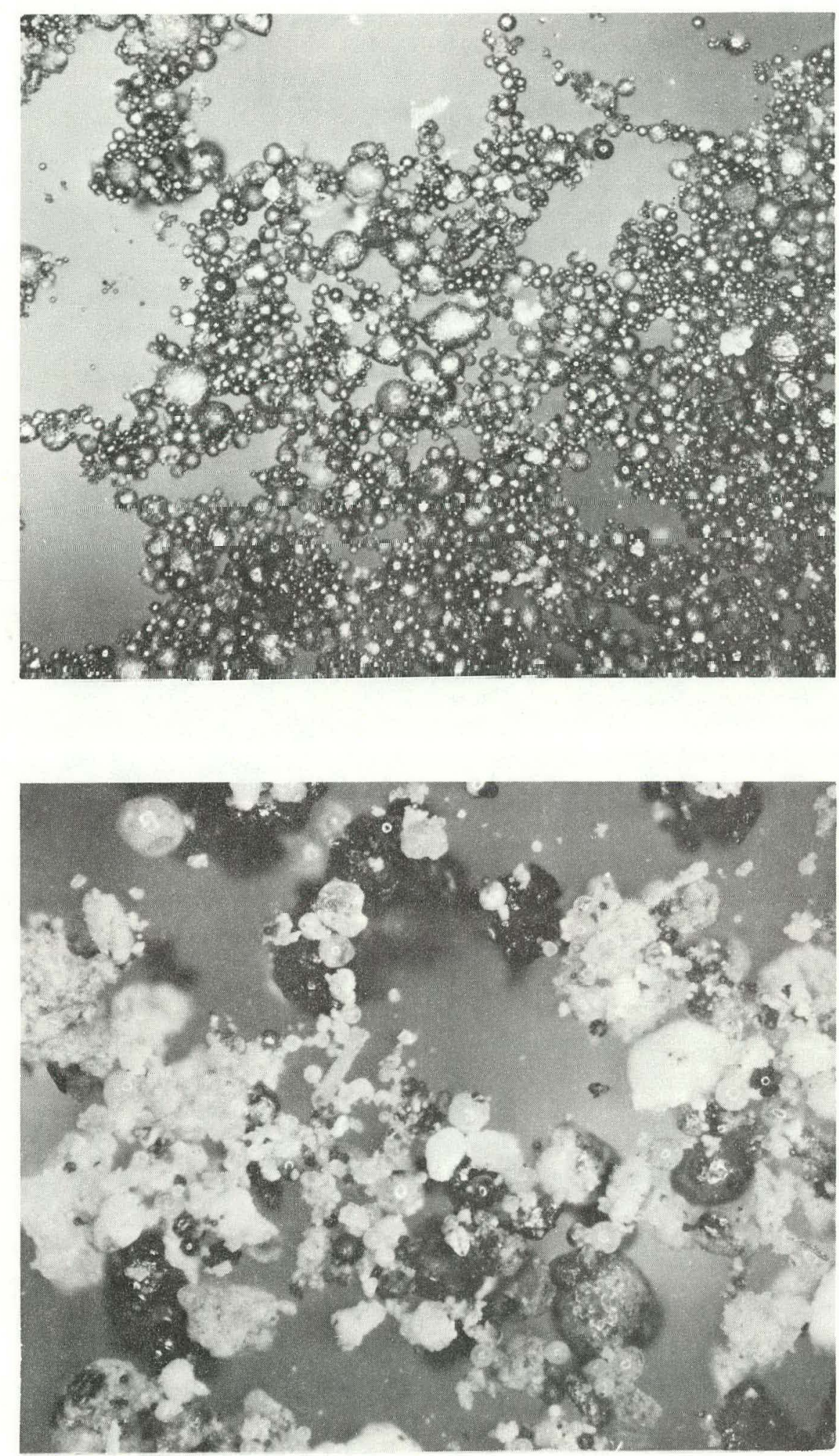
agglomeration probably occurs in the coal burner. Some angular particles are white or colorless. They are probably quartz. There are a few dark round particles, probably mixtures of magnetite and hematite. Those white, shiny and round particles are cenospheres. Carbon is present in big black solids of irregular shapes.

Figure 8 shows an ash sample after being chlorinated at $800^{\circ} \mathrm{C}$ for 1 hour. Here the dark round and slightly colored particles are noticeably absent. There is, however, an increase of white irregular-shaped particles which probably are silica. The shiny particles are added graphite.

Results of the Effect of High Temperature Chlorination Variables

The major variables under investigation in this research are the reaction time, the temperature and the chlorine flow rate. Data showing the effects of these variables are presented in the following sections. Emphasis will be on alumina recovery. The reaction time is 2 hours with an interval of 30 minutes for each temperature; the temperature ranges from 750 to $900^{\circ} \mathrm{C}$. Two chlorine flow rates, $3.1 \mathrm{x}$ $10^{-4}$ and $1.8 \times 10^{-3} \mathrm{~g}$ moles $/ \mathrm{min}$, are used. 


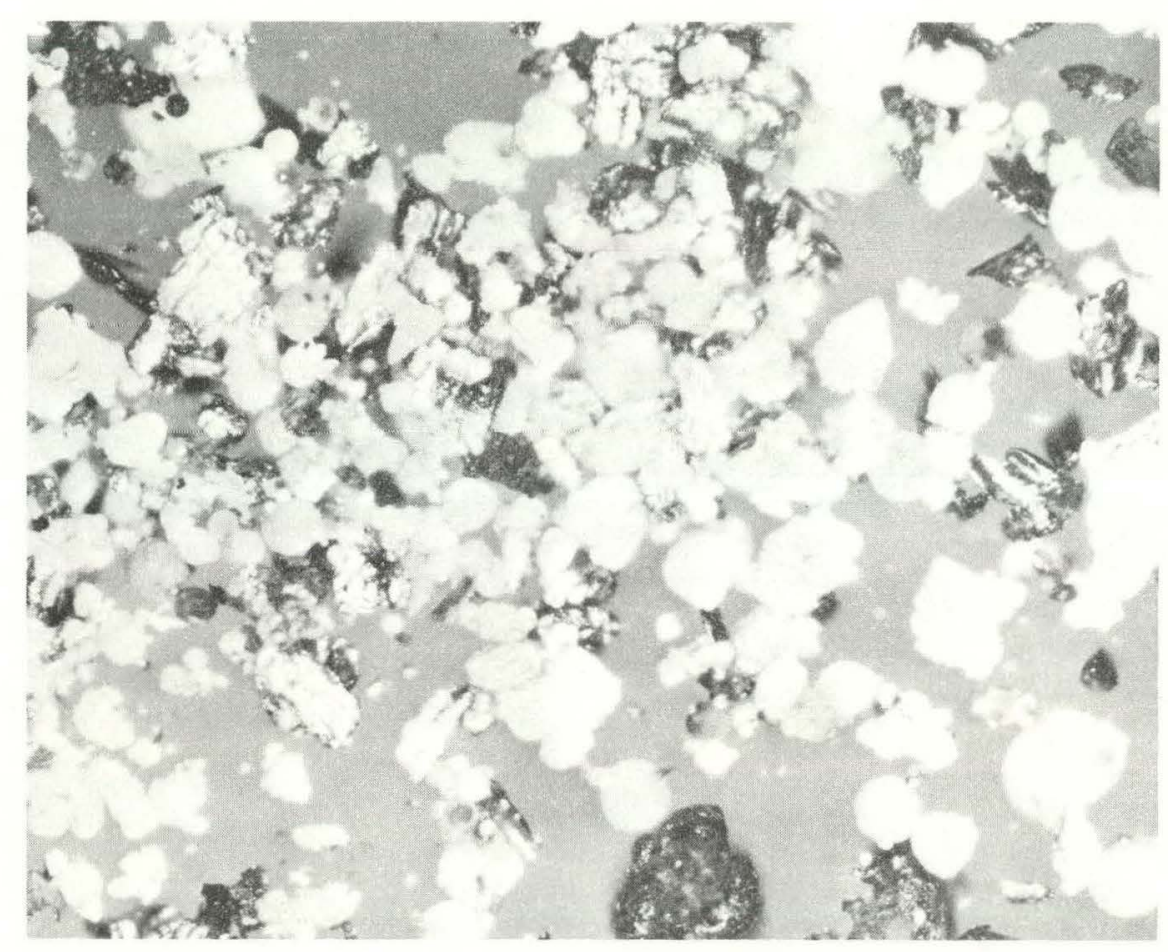

Figure 8. Photomicrograph of the nonmagnetic ash after being chlorinated at $800^{\circ} \mathrm{C}$ for 1 hour at $100 \mathrm{X}$. Note the absence of dark round and slightly colored particles 
Effect of reaction time and temperature

The reduction chlorination reaction, $\mathrm{Al}_{2} \mathrm{O}_{3}(\mathrm{~s})+3 \mathrm{Cl}_{2}(\mathrm{~g})+$ $3 \mathrm{C}(\mathrm{s}) \rightarrow 2 \mathrm{AlCl}_{3}(\mathrm{~g})+3 \mathrm{CO}(\mathrm{g})$, is exothermic and the time required for reaction is short at high temperature (48). It is expected that the chemical reaction between the chlorine and the alumina is rapid and hence not a controlling step. Figure 9 shows the amount of alumina recovery in weight percent as a function of time for different temperatures. Figure 10 shows the amount of alumina recovery as a function of temperature. Figure 11 gives the avèrage reaction rate of alumina with chlorine as a function of temperature.

It was expected that the higher the temperature, the higher the alumina recovery. But Figure 9 shows that for the first hour, the alumina recovery was lower at higher temperatures. This can be explained as follows: c-l fly ash consists of not only $\mathrm{Fe}_{2} \mathrm{O}_{3}, \mathrm{Al}_{2} \mathrm{O}_{3}$ and $\mathrm{SiO}_{2}$, but also CaO, $\mathrm{K}_{2} \mathrm{O}, \mathrm{Na}_{2} \mathrm{O}$ and $\mathrm{MgO}$. In the nonmagnetic fraction of $\mathrm{C}-1 \mathrm{fly}$ ash, Cao constitutes about $5.36 \%$ by weight (Table 4). Table 6 (80) gives the difference between the Gibbs free energy of the chlorides and the oxides in the reduction chlorination reaction at different temperatures. The negative values of the Gibbs free energy indicate favorable reactions. All calculations are based on reactions with six chlorine atoms. Table 6 shows $\mathrm{CaO}, \mathrm{K}_{2} \mathrm{O}, \mathrm{Na}_{2} \mathrm{O}$ and MgO all have higher 


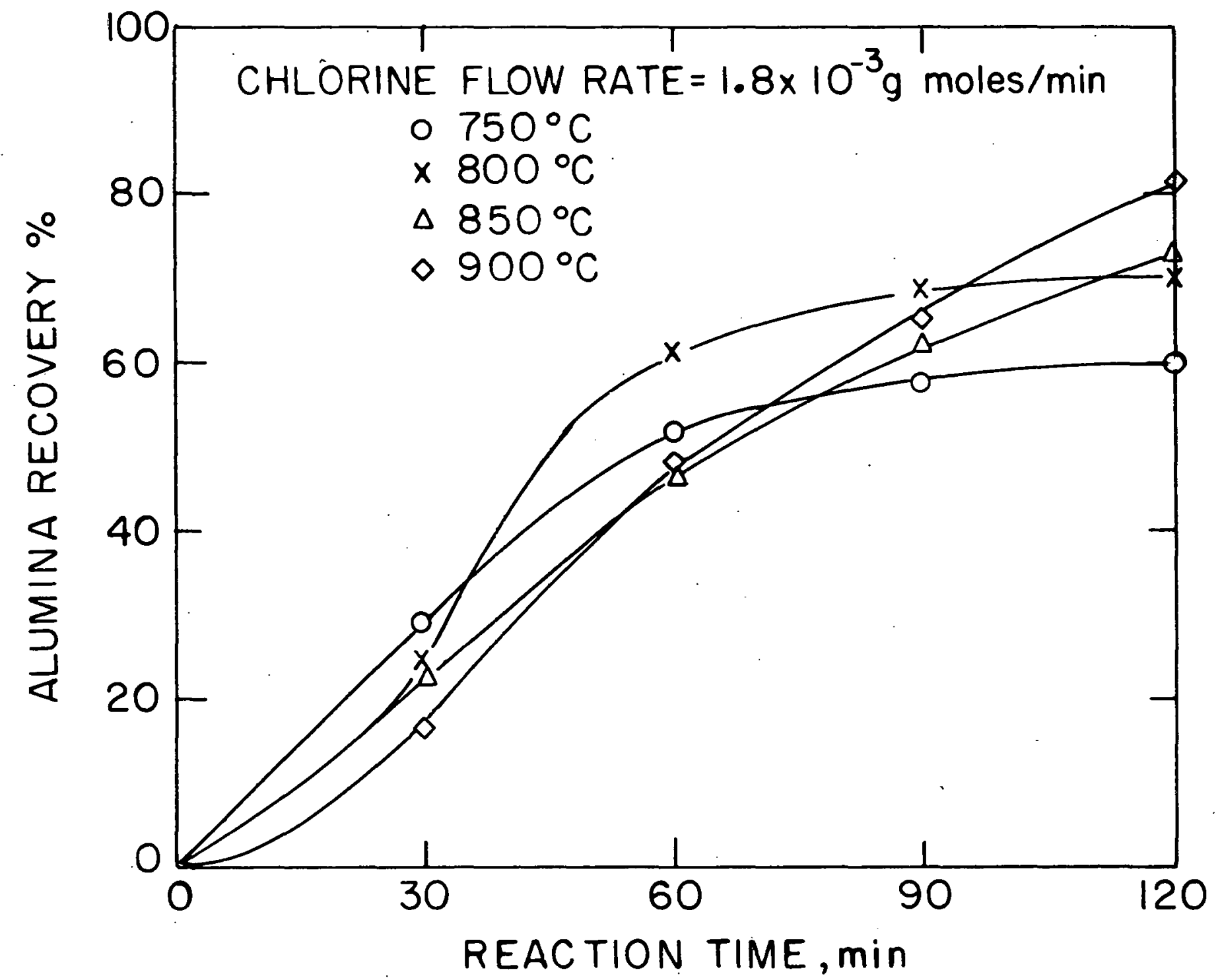

Figure 9. The effect of reaction time on alumina recovery at different temperatures 


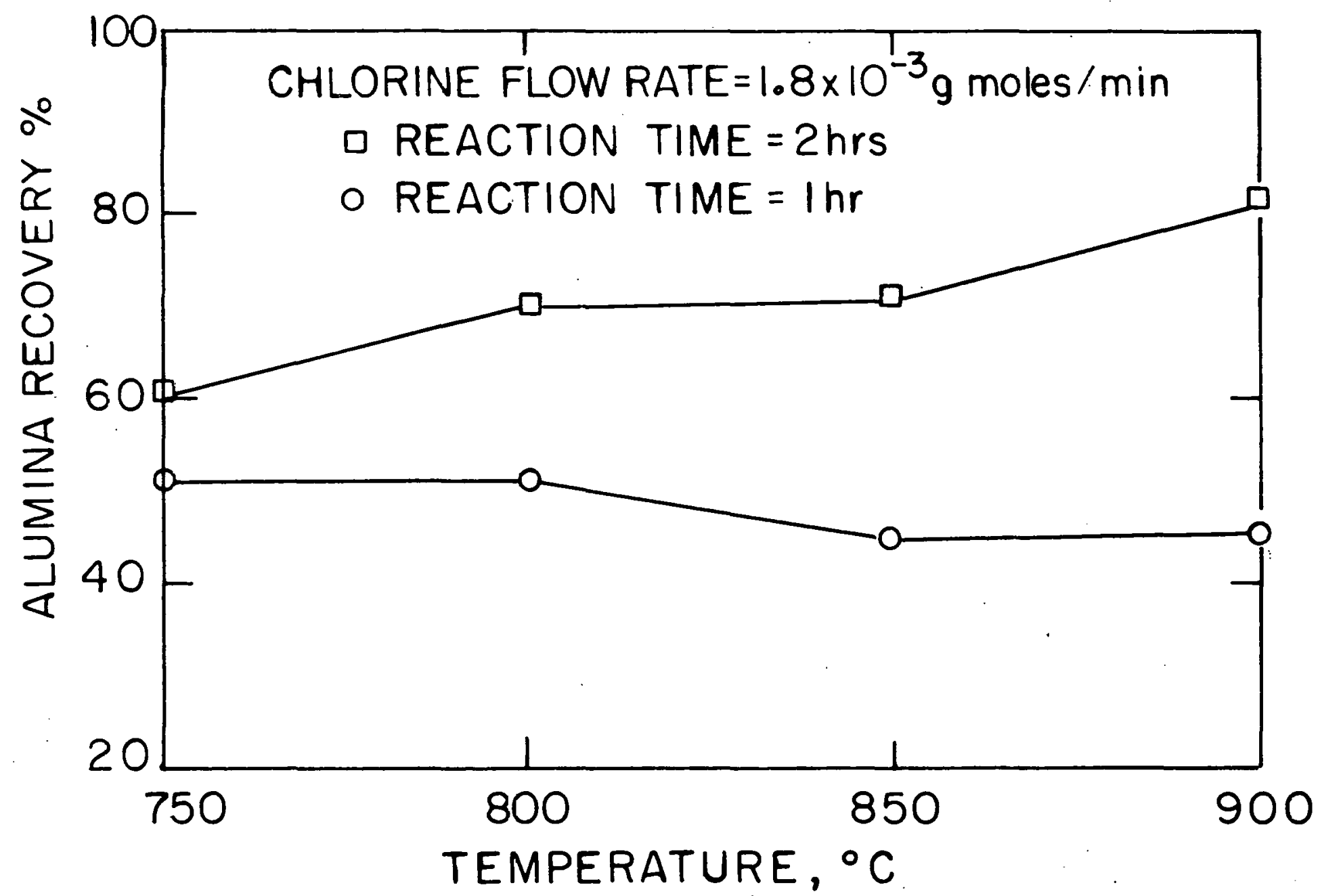

Figure 10. The effect of temperature on alumina recovery 


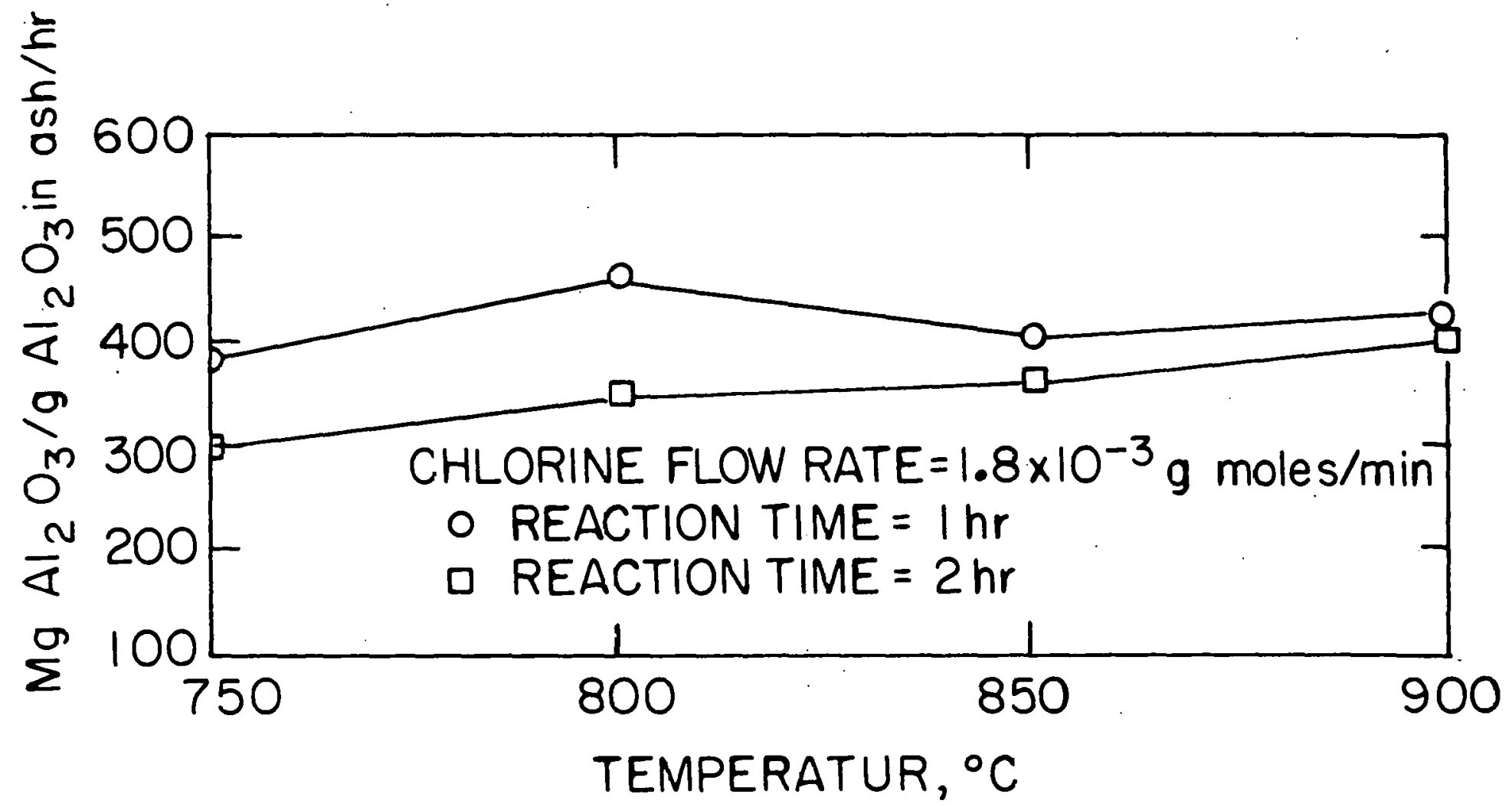

Figure 11. The effect of temperature on the average reaction rate of alumina with chlorine 
Table 6. Differences between Gibbs free energy, kcal, of metallic chlorides and oxides for the reduction chlorination reaction (80)

\begin{tabular}{lcccc}
\hline Metals & \multicolumn{4}{c}{ Temp., ${ }^{\circ} \mathrm{C}$} \\
\cline { 2 - 4 } $\mathrm{K}$ & -400 & 800 & 850 & 900 \\
$\mathrm{Na}$ & -476.36 & -483.72 & -493.65 & -516.60 \\
$\mathrm{Ca}$ & -405.66 & -408.75 & -411.87 & -415.08 \\
$\mathrm{Mg}$ & -230.55 & -229.95 & -238.92 & -244.95 \\
$\mathrm{Fe}$ & -136.71 & -140.19 & -143.58 & -146.88 \\
$\mathrm{Al}$ & -144.21 & -153.21 & -165.35 & -170.45 \\
$\mathrm{Si}$ & -73.53 & -86.20 & -91.98 & -96.39 \\
& -79.73 & -83.12 & -83.39 & -89.43 \\
\hline
\end{tabular}


chlorine affinities than $\mathrm{Fe}_{2} \mathrm{O}_{3}, \mathrm{Al}_{2} \mathrm{O}_{3}$ and $\mathrm{SiO}_{2}$. As a result, it is very likely that $\mathrm{CaCl}_{2}, \mathrm{KCl}, \mathrm{NaCl}$ and $\mathrm{MgCl}_{2}$ are formed along with $\mathrm{FeCl}_{3}, \mathrm{AlCl}_{3}$ and $\mathrm{SiCl}_{4}$, on the condition of sufficient chlorine. CaO, being a major constituent, will form $\mathrm{CaCl}_{2}$ that probably has a significant effect on the volatility of the chloride products. Dewing (21) reported that in the presence of $\mathrm{AlCl}_{3}$, the volatility of dichlorides, $\mathrm{CaCl}_{2}$ and $\mathrm{MgCl}_{2}$, for example, is much enhanced due to the formation of gaseous complexes, $\mathrm{CaCl}_{2} \cdot 2 \mathrm{AlCl}_{3}$ and $\mathrm{MgCl}_{2} \cdot 2 \mathrm{AlCl}_{3} \cdot$ He found that the vapor pressures of these dimers decrease as temperature increases. In other words, $\mathrm{CaCl}_{2} \cdot 2 \mathrm{AlCl}_{3}, \mathrm{MgCl}_{2} \cdot 2 \mathrm{AlCl}_{3}$ and possibly $\mathrm{KCl} \cdot \mathrm{AlCl}_{3}$ and $\mathrm{NaCl} . \mathrm{AlCl}_{3}$ are more volatile at low temperatures. Table 7 (21) shows the partial pressures of $\mathrm{CaCl}_{2} \cdot 2 \mathrm{AlCl}_{3}$ at different temperatures. The total pressure is about one atmosphere. These gaseous complexes, once formed, would be removed more easily at lower temperatures. The removal of the dimers would help the chlorine gas contact with more fly ash particles and hence result in higher alumina recovery. But after the first hour, as shown in Figure 9, the alumina recovery at $750^{\circ} \mathrm{C}$ and $800^{\circ} \mathrm{C}$ began to level off. This did not happen at $850^{\circ} \mathrm{C}$ and $900^{\circ} \mathrm{C}$. The alumina recovery seemed to be increasing with increase in temperature. Watt and Thorne $(76,77)$ have verified the presence of mullite, 
Table 7. Partial pressures of $\mathrm{CaCl}_{2} \cdot 2 \mathrm{AlCl} \mathrm{Cl}_{3}$ as a function of temperature in the presence of aluminum chloride (21)

\begin{tabular}{lccc}
\hline State & Temp. ${ }^{\circ} \mathrm{C}$ & $\begin{array}{c}\text { Total Pressure, } \\
\text { Torr }\end{array}$ & $\begin{array}{c}\mathrm{p} \mathrm{CaCl}_{2} \cdot 2 \mathrm{AlCl}_{3}{ }^{\prime} \\
\text { Torr }\end{array}$ \\
\hline Solid & 540 & 753 & 33.0 \\
& 650 & 748 & 23.2 \\
& 700 & 744 & 14.6 \\
& 757 & 752 & 10.1 \\
Liquid & 893 & 750 & 5.0 \\
& 895 & 750 & 4.4 \\
\hline
\end{tabular}


$3 \mathrm{Al}_{2} \mathrm{O}_{3} \cdot 2 \mathrm{SiO}_{2}$ in $\mathrm{fly}$ ash by $\mathrm{x}$-ray diffraction studies. Mullite in fly ash is probably formed as a result of the kaolinite-mullite reaction series, proposed by Brindley and Nakahira (12, 13). According to Brindley and Nakahira (12, 13) kaolinite transforms into mullite by the following reactions :

$$
\begin{aligned}
& \mathrm{Al}_{2} \mathrm{O}_{3} \cdot 2 \mathrm{SiO}_{2} \cdot 2 \mathrm{H}_{2} \mathrm{O} \stackrel{500^{\circ} \mathrm{C}}{\rightarrow} \mathrm{Al}_{2} \mathrm{O}_{3} \cdot 2 \mathrm{SiO}_{2}+2 \mathrm{H}_{2} \mathrm{O} \\
& \text { kaolinite metakaolin } \\
& 2\left(\mathrm{Al}_{2} \mathrm{O}_{3} \cdot 2 \mathrm{SiO}_{2}\right) \stackrel{925^{\circ} \mathrm{C}}{\rightarrow} 2 \mathrm{Al}_{2} \mathrm{O}_{3} \cdot 3 \mathrm{SiO}_{2}+\mathrm{SiO}_{2} \\
& \text { metakaolin spinel-type phase } \\
& \begin{array}{l}
3\left(2 \mathrm{Al}_{2} \mathrm{O}_{3} \cdot 3 \mathrm{SiO}_{2}\right) \stackrel{1,050-1,100^{\circ} \mathrm{C}}{\rightarrow} \begin{array}{c}
\text { transformation to } \\
\text { mullite phase }
\end{array} \\
\text { spinel-type phase }
\end{array} \\
& 1,200-1,400^{\circ} \mathrm{C} \\
& \underset{2\left(3 \mathrm{Al}_{2} \mathrm{O}_{3} \cdot 2 \mathrm{SiO}_{2}\right)}{\text { mulite }}+\underset{\text { cristobalite }}{5 \mathrm{SiO}_{2}}
\end{aligned}
$$

Analyses of a number of United States coals have shown that 70-95\% of the mineral matter in the coals is kaolinite $(30,46,70)$. Nelson (46) reported that temperature in a pulverized-coal burner ranged from $1,300-1,700^{\circ} \mathrm{C}$. Cristobalite has a melting point of $1,600-1,700^{\circ} \mathrm{C}$ (46) and mullite is very stable and does not melt until $1,850^{\circ} \mathrm{C}$ (16). As a result, some cristobalite might have melted inside the coal 
burner while mullite did not. It is quite possible that as the fly ash particles were leaving the burner in the flue gas and as the temperature was decreasing, some of the mullite was glazed with silica on the surface. These silicacoated mullite particles would have their alumina protected from being reached by the chlorine gas. Chlorine gas attacks silica more readily at high temperatures than at low temperatures $(20)$. It is believed that at $750-800^{\circ} \mathrm{C}$ the reaction rate between chlorine and silica is so low that the reaction practically stops. At $850-900^{\circ} \mathrm{C}$, silica reacts more readily with chlorine and hence more alumina molecules are exposed. This results in higher alumina recovery. Another possible explanation for this behavior is that the chlorination reaction of $f l y$ ash is primarily diffusion controlled. Figure 11 shows the slight temperature dependency of the reaction rate. As more and more alumina is reacted and removed from the mullite particle surface, the chlorine will have to diffuse through or react with the silica. This will slow down the reaction. In order to continue the reaction a higher temperature is needed. 
Effects of chlorine flow rate and temperature

Figure 12 shows two series of runs with two different flow rates and temperatures ranging from $750^{\circ}$ to $900^{\circ} \mathrm{C}$. The reaction time is 2 hours. Again the slight temperature dependency of the chlorination reaction is depicted by the almost straight-line relationship between the rate of reaction and the temperature. Figure 13 shows the alumina recovery as a function of the chlorine flow rate. Figure 14 shows the considerable change of the reaction rate as the chlorine flow rate is varied from $3.1 \times 10^{-4}$ to $1.8 \times 10^{-3}$ $g$ moles/min. Excess chlorine is detected when the flow rate is $1.8 \times 10^{-3} \mathrm{~g}$ moles/min. Since the chemical reaction between $\mathrm{Al}_{2} \mathrm{O}_{3}$ and $\mathrm{Cl}_{2}$ is rapid, it is not a controlling step. It is believed that gas film diffusion is the major ratecontrolling step. As chlorine gas comes into contact with a fly ash particle, a gas film is formed around this particle. The particle can either be porous or nonporous. It is further thought that as the reaction continues, the particle shrinks in size. Higher gas velocities will enhance the mass transfer rate because the gas film around the particle decreases in thickness with increase in gas velocities. This results in higher reaction rates and hence higher recovery. 


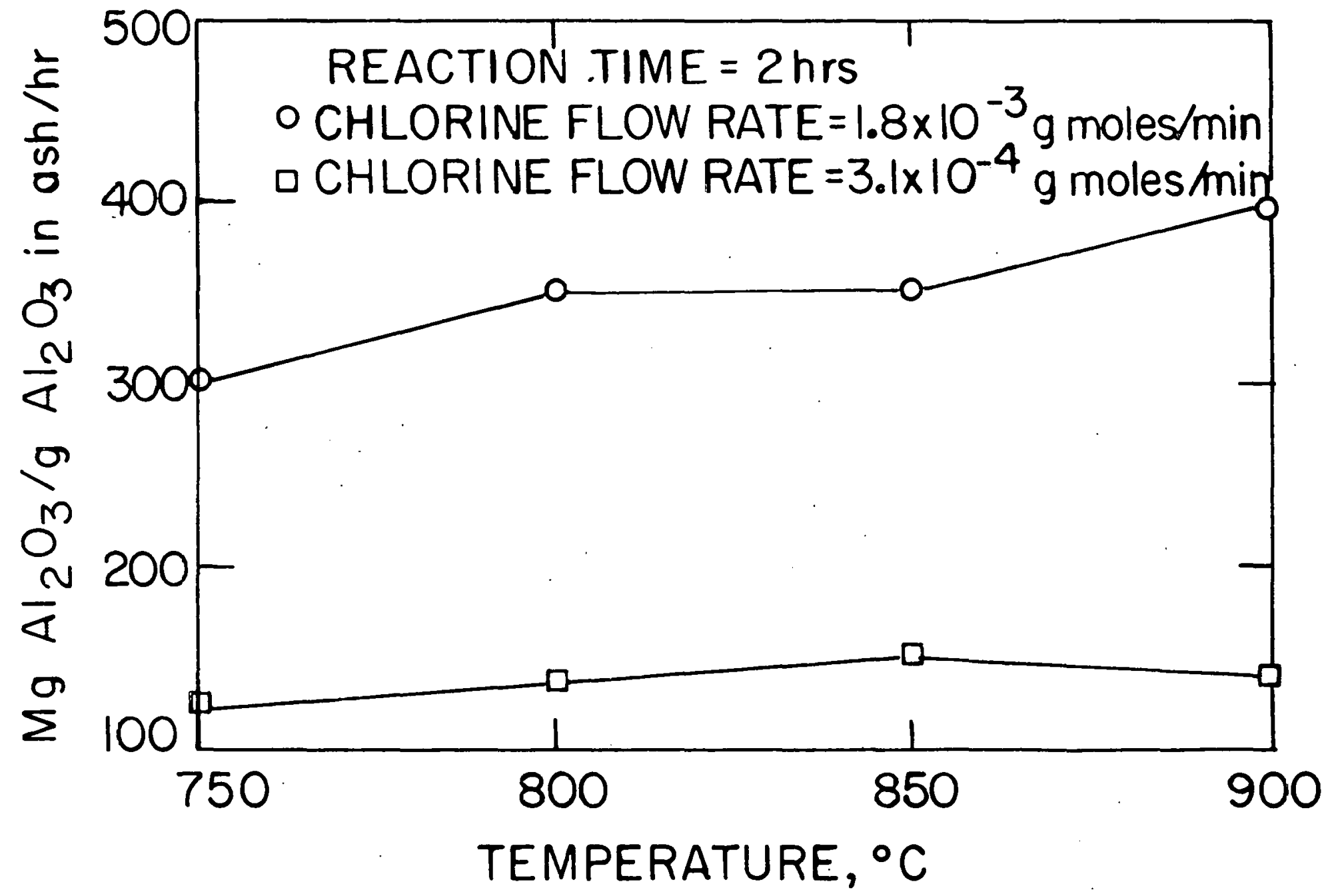

Figure 12. The effect of temperature on the average reaction rate of alumina with chlorine at different flow rates 


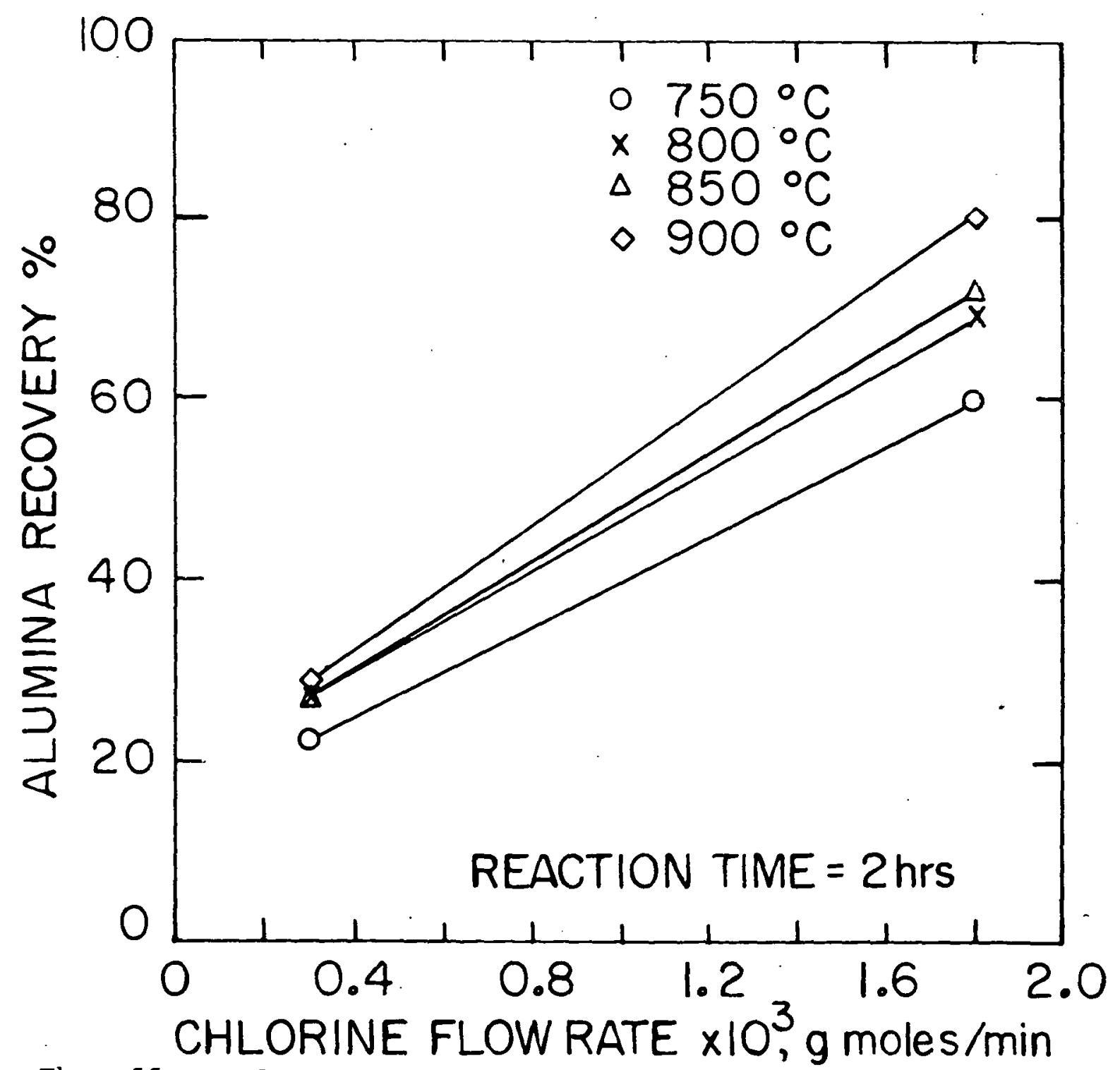
Figure 13. The effect of chlorine flow rate on alumina recovery at different
temperatures 


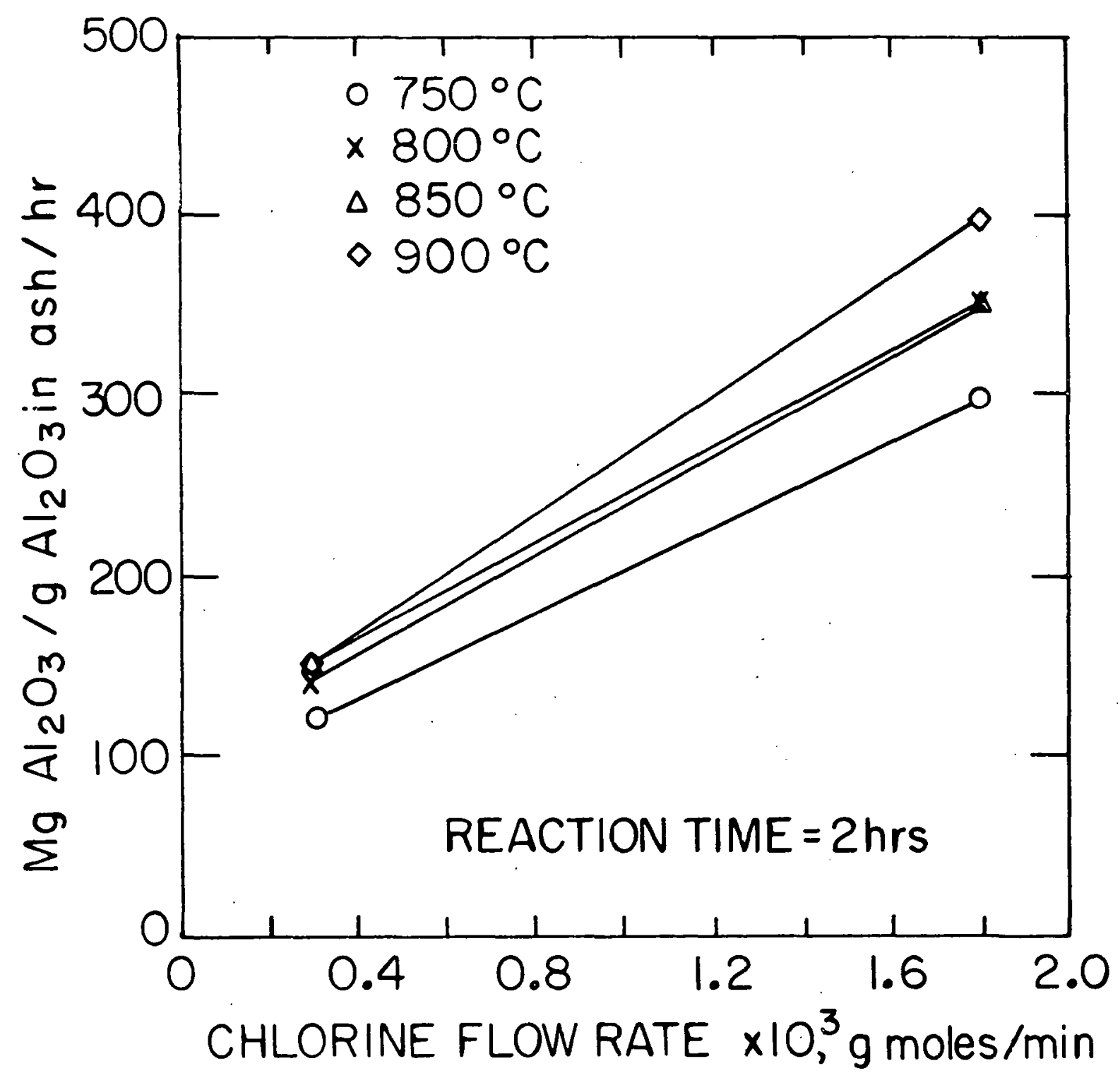

Figure 14. The effect of chlorine flow rate on the average reaction rate of alumina with chlorine at different temperatures 


\section{CONCLUSIONS}

Some iron oxide in the fly ash is agglomerated with alumina and silica. This makes complete iron separation by magnetic means difficult. About $6.64 \%$ by weight of the iron oxide, $\mathrm{Fe}_{2} \mathrm{O}_{3}$, is left in the nonmagnetic fraction.

The iron oxide in the nonmagnetic fraction can be further separated by chlorination reaction at $550^{\circ} \mathrm{C}$ for 30 minutes. About $40 \%$ of the iron oxide is removed with less than $2 \%$ of the alumina being chlorinated.

The chlorine flow rate affects the rate of reaction substantially, but the temperature has a lesser effect. The chemical reaction between chlorine and alumina in the presence of carbon is exothermic and rapid, and so not controlling. This suggests that gas film diffusion is the major controlling step.

$\mathrm{CaO}, \mathrm{K}_{2} \mathrm{O}, \mathrm{Na}_{2} \mathrm{O}$ and $\mathrm{MgO}$ form individual chlorides during this reduction chlorination reaction. These chlorides, particularly $\mathrm{CaCl}_{2}$, and $\mathrm{MgCl}_{2}$ form gaseous complexes, such as $\mathrm{CaCl}_{2} \cdot 2 \mathrm{AlCl}_{3} \cdot \mathrm{MgCl}_{2} \cdot 2 \mathrm{AlCl}_{3}$ and possibly KCl.AlCl 3 and $\mathrm{NaCl} . \mathrm{AlCl}_{3}$. The presence of these gaseous complexes enhances the volatility of those chlorides formed. The partial pressures of these complex species decrease with increasing temperature. This probably accounts for the higher alumina recovery at $750^{\circ}$ and $800^{\circ} \mathrm{C}$. 
Some mulite particles in fly ash are probably glazed with silica. This makes it difficult for chlorine to react with the alumina molecules in the mullite at a temperature below $850^{\circ} \mathrm{C}$. 


\section{RECOMMENDATIONS}

From the results of this exploratory work, the following recommendations are given for future research:

1. Investigate the possibility of separating iron oxide from the nonmagnetic ash fraction through some acid leaching. Such studies should focus upon the optimization of acid strength, temperature, pressure, reaction time and grinding of ash particles for maximum iron separation.

2. Investigate some methods for separating $\mathrm{CaO}, \mathrm{K}_{2} \mathrm{O}$ $\mathrm{Na}_{2} \mathrm{O}$ and $\mathrm{MgO}$ from the nonmagnetic ash fraction.

3. Investigate the possibility of recycling $\mathrm{SiCl}_{4}$ formed to try to suppress the chlorination of $\mathrm{SiO}_{2}$ in the ash.

4. Study the effect of different carbon content in the ash on the chlorination reaction. This should focus on the degree of mixing of the carbon and ash, and grinding to ensure maximum contact surfaces.

5. Use co instead of carbon as the reducing agent and a mixture of $\mathrm{Cl}_{2}$ and $\mathrm{HCl}$ instead of $\mathrm{Cl}_{2}$ alone to explore better reaction conditions for this reduction chlorination process.

6. Investigate some methods for purifying the final aluminum product. Since iron presents the most 
serious contamination problem, this research should focus on separating the iron from the aluminum product.

7. Investigate the glazing phenomenon that might have happened since $\mathrm{CaO}, \mathrm{K}_{2} \mathrm{O}, \mathrm{Na}_{2} \mathrm{O}$ and $\mathrm{MgO}$ all form chlorides more readily than $\mathrm{Fe}_{2} \mathrm{O}_{3}, \mathrm{Al}_{2} \mathrm{O}_{3}$ and $\mathrm{SiO}_{2}$. The chlorides formed have low melting points, from $700^{\circ}$ to $800^{\circ} \mathrm{C}$, but high boiling points, from $1,400^{\circ}$ to $2,027^{\circ} \mathrm{C}$. If these chlorides form mixtures, they will have eutectic points ranging from $475^{\circ}$ to $670^{\circ} \mathrm{C}$.

8. Investigate the possibility of using a fluidized bed instead of a packed bed. 


\section{REFERENCES}

1. Alumina producers look to alternative raw materials. Chemical Engineering 81(17):98. April 29, 1974 .

2. Anderson, R. J. The metallurgy of aluminum and aluminum alloys. Henry Carey Baird and Co., Inc. New York, New York. 1925.

3. Another report warns of minerals shortage. Chemical and Engineering News 53(30):5. July 28, 1975.

4. Archibald, F. R., and Nicholson, C. M. Alumina from clay by the lime-sinter method II. Trans. AIMME 182: $14-38$. 1949 .

5. Babcock and Wilcox Company. Steam - Its generation and use. Author, New York, N.Y. 1972.

6. Bailey, R. V. and Toth, C. Process for the continuous production of aluminum. U.S. Patent $3,615,360$. Oct. 26, 1971 .

7. Ball, C. G. Contributions to the study of coal. Illinois State Geological Survey, Report Investigation No. 33. 1935 .

8. Balzhizer, R. E. Energy option to the year 2000. Chemical Engineering 24(1):73-90. January 3, 1977.

9. Boux, J. F. Canadians pioneer new fly ash processing system. Minerals Processing 10:16-19. 1969.

10. Brackett, C. E. Availability, quantity and present utilization of fly ash. Paper in "Fly Ash Utilization." U.S. Bureau of Mines, Information Circular 8348:16-. 36. 1967.

11. Brackett, C. E. Production and utilization of fly ash in the United States. Paper in "Ash Utilization." U.S. Bureau of Mines, Information Circular 8640:1218. 1974.

12. Brindley, G. W., and Nakahira, M. The kaolinitemullite reaction series: II. Metakaolin. American Ceramic Society Journal 42:314-318. 1959. 
13. Brindley, G. W., and Nakahira., M. The kaolinite-muliite reaction series: III. The high temperature phases. American Ceramic Society Journal 42:319-324. 1959.

14. Capp, J. P., and Spencer, J. D. Fly ash utilization. A summary of applications and technology. U.S. Bureau of Mines, Information Circular 8483:2-65. 1970 .

15. Cavin, D. C. A study of iron and aluminum recovery from power plant fly ash. Unpublished M.s. thesis. Library, Iowa State University, Ames, Iowa. 1973.

16. Chou, K. S. A study of the extractability of alumina from fly ash by the lime-sinter process. M.S. thesis. Library, Iowa State University, Ames, Iowa. 1970.

17. Clendenning, T. G., and Durie, N. D. Properties and uses of fly ash from a steam plant operating under variable load. ASTM Proceedings 62:1014-1037. 1962.

18. Coal seen as answer to energy crisis. Chemical and Engineering News 53(24):6. June 16, 1975.

19. Collins, R. J. Waste products as a potential replacement for aggregates. Proceedings 4 th International Ash Utilization Symposium. St. Louis, Mo. March 24$25,1976$.

20. de Beauchamp, R. L. Preparation of anhydrous aluminum chloride. U.S. Bureau of Mines Information Circular 8412, $1-19,1969$.

21. Dewing, E. W. Gaseous complexes formed between trichlorides $\left(\mathrm{F}_{\mathrm{lCl}}\right.$ and $\left.\mathrm{FeCl}_{3}\right)$ and dichlorides. Metallurgical Transactions $1: 2169-2172$. August, 1970 .

22. Edwards, J. D., Frary, F, C., and Jefferies, Z. Aluminum and its production. Vol. I. McGraw-Hill Book Co., Inc., New York, N.Y. 1930.

23. Edwards, J. D. The combination process for alumina, Trans. AIMME 182:9-13. 1949.

24. Eisele, J. A., Schultze, L. Z ., Berinati, D, J. and Bauer, D. J. Amine Extraction of iron from aluminum chloridc leached Iiquous. U.S. Bureau of Mines Report of Investigations 8188:1-9. 1976. 
25. Faber, J. H. U.S. overview of ash production and utilization. Proceedings 4 th International Ash Utilization Symposium. St. Louis, Mo. March 24$25,1976$.

26. Fetterman, J. W., and Shiou-Chuan Sun. Alumina extraction from a Pennsylvania diaspore clay by an ammonium sulfate process. AIMME International Symposium on the Extractive Metallurgy of Alumina Proceedings: Alumina $1: 305-322$. 1962 .

27. Flint, E. P., Clarke, W. F., Newman, E. S., Shartsis, L., Bishop, D. I., and Wells, L. S. Extraction of alumina from clays and high-silica bauxites. Journal of Research of the National Bureau of Standards (RP 1691) 36:63106. 1946 .

28. Fly and Bottom Ash. Mining Engineers No. 176-185-37. March 28, 1976 .

29. Good, P. C., Butler, M. O. and Yerkes, L. A. Electrodeposition of aluminum from fused-salt electrolytes containing aluminum chloride. U.S. Bureau of Mines Report of Investigations 6785:1-13. 1966.

30. Gumz, W. Coal minerals and their importance to boiler design and operation - I. Combustion $27(10): 47-54$. 1956 .

31. Henn, J. J., Johnson, P. W., Amey III, E. B., and Peters, F. A. Methods for producing alumina from clay. An evaluation of two lime sinter processes. U.S. Bureau of Mines, Report of Investigation 7299:1-43. 1969.

32. Johnson, P. W., F. A. Peters and R. C. Kirby. Method for producing alumina from clay. An evaluation of a nitric acid process. U.S. Bureau of Mines Report of Investigations $5431,1-25,1964$.

33. Johnson, P. W. and Peters, F. A. Methods for producing alumina from anorthosite. An evaluation of a limesoda sinter process. U.S. Bureau of Mines Report of Investigations 7068:2-19. 1968.

34. Joshi, R. C. Pozzolanic reactions in synthetic fly ashes. Unpublished Ph.D. thesis. Library, Iowa State University, Ames, Iowa. 1970. 
35. Kirby, D. Z., Singleton, E. L. and Sullivan T. A. Electrowinning aluminum from aluminum chloride; operation of a single-component cell. U.S. Bureau of Mines Report of Investigations 7353:1-23. 1970 .

36. Klemm, W. A. Fly ash as a source of iron and alumina. Unpublished memo to Dr. George Burnet, August 1975. Iowa State University, Department of Chemical Engineering and Nuclear Engineering, Ames, Iowa. August 1975.

37. Landsberg, A. Chlorination kinetics of aluminum bearing minerals. Metallurgical Transactions B:207-214. June 1975.

38. Leonard, $R$. J. The pozzolanic reactivity of certain fly ashes and soil minerals. Unpublished Ph.D. thesis. Library, Iowa State University, Ames, Iowa. 1958.

39. Littlejohn, R. F. Mineral matter and ash distribution in as-fired of pulverized fuels. Institute of Fuel Journal 29:59-67. 1966 .

40. Mateos, M., and Davidson, D. T. Steam curing and Xray studies of fly ashes. ASTM Proceedings 62:10081011. 1962 .

41. Mineral shortages in U.S. growing serious. Chemical and Engineering News 51(20:14. 21 May, 1973.

42. Minnick, L. J. Fundamental characteristics of pulverized coal fly ashes. ASTM Proceedings 59:1155-1177. 1959.

43. Minnick, L. J. The application of rotoflux magnetic separator to pulverized coal fly ash. ASME Paper 61-WA-313. 1961 .

44. Minnick, L. J. Fly ash: Now meets lightweight aggregate specifications. Brick and Clay Record 146(4):78. 1965.

45. Morrison, R. Z . Power plant ash: A new mineral resource. Proceedings 4 th International Ash Utilization Symposium. St. Louis, Mo. March 24-25, 1976.

46. Nelson, H. W. Mineral constituents in coal and in heavy fuel oil and their behavior during combustion. In ASTM book "Corrosion and deposits in coal- and oil-fired boiler and gas turbines." ASTM, New York, N.Y. 1959. 
47. New processes promise lower-cost aluminum. Chemical and Engineering News 51(8):11-12. February 26, 1973.

48. Nowak, R. and Schuster, W. Hallide process for extraction of iron from iron-oxide-bearing materials. U.S. Patent 3,244,509. April 5, 1966 .

49. Nowak, R. and Schuster, W. Process for the production of metallic chlorides from substances containing metallic oxides. U.S. Patent 3,466,169. September 9, 1969 .

50. Nowak, hab. inz. Zygfrad. Iron and alumina extraction from power plant fly ash in Poland. Paper in "Ash Utilization." U.S. Bureau of Mines, Information Circular 8640:224-230. 1974 .

51. Othmer, D. F. and Nowak, R. Halogen affinities - A new ordering of metals to accomplish difficult separations. American Institute of Chemical Engineers Journal $18(1): 217$. January, 1972 .

52. Outlook grim for U.S. energy independence. Chemical and Engineering News 53(8):5. February 17, 1975.

53. Pearson, T. G. The chemical background of the aluminum industry. The Royal Institute of Chemistry Lectures, Monographs and Reports No. 3:2-99. 1955.

54. Pedlow, J. W. Cenospheres. Paper in "Ash Utilization." U.S. Bureau of Mines, Information Circular 8640:3343. 1974 .

55. Peters, F. A., Johnson, P. W., and Kirby, R. C. Methods for producing alumina from clay. An evaluation of the sulfurous acid-caustic purification process. U.S. Bureau of Mines, Report of Investigation 5997:2-21. 1962 .

56. Peters, F. A., Johnson, P. W., and Kirby, R. C. Methods for producing alumina from clay. An evaluation of five hydrochloric acid processes. U.S. Bureau of Mines, Report of Investigation 6133:1-68. 1962 . 
57. Peters, F. A., Johnson, P. W., and Kirby, R. C. Methods for producing alumina from clay. An evaluation of theee sulfuric acid processes. U.S. Bureau of Mines, Report of Investigation 6229:2-57. 1963.

58. Peters, F. A., Johnson, P. W., and Kirby, R. C. Methods for producing alumina from clay. An evaluation of a potassium alum process. U.S. Bureau of Mines, Report of Investigation 6290:1-27. 1963.

59. Peters, F. A., P. W. Johnson, J. J. Henn and R. C. Kirby. Methods for producing alumina from dlay: An evaluation of two ammonium alum process. U.S. Bureau of Mines Report of Investigations 6573:1-47. 1965.

60. Peters, F. A. and Johnson, P. W. Revised and updated cost estimates for producing alumina from domestic raw materials. U.S. Bureau of Mines Information Circular $8648: 1-51$. 1974 .

61. Peters, F. A., P. W. Johnson, J. J. Henn, and R. C. Kirby. Methods for producing alumina from clay. An evaluation of a lime-soda sinter process. U.S. Bureau of Mines Reports of Investigations 6927:1-38. 1967.

62. Pribil, R., and Vesely, V. Contributions to the basic problems of complexometry - IX. The determination and masking of alumina. Talanta 9:23-26. 1962.

63. PUK process separates aluminum from loss-grade ore. Chemical and Engineering News 53(13):20. April 7, 1975 .

64. Seimiya, S. Some properties of sodalite in red mud. AIMME International Symposium on the Extractive Metallurgy of Alumina Proceedings: Alumina 1:115-132. 1962 .

65. Simons, H. S. and Jeffery, J. W. An X-ray study of pulverized fuel ash. Journal of Applied Chemistry 10: 328-336. 1960 .

66. Singleton, E. L., Kirby, D. Z . and Sullivan, T. A. Electrowinning aluminum from aluminum chloride: Operation of a two-component cell. U.S. Bureau of Mines Report of Investigations 7212, 1-15. 1968. 
67. Slonaker, J. F. and Leonard J.W. Review of current research on coal ash in the United States. Paper in "Ash Utilization." U.S. Bureau of Mines, Information Circular 8640:26-30. 1974 .

68. Standard method of analysis of coal and ash. Pages 540-547 in 1974 Annual Book of ASTM Standards. ASTM, Philadelphia, Pennsylvania. 1974.

69. St. Clair, H. W., Ravitz, S. F., Swett, A. T., and Plummer, C. E. The ammonium sulfate process for production of alumina from western clays. Trans. AIMME 159: 255-266. . 1944 .

70. Styron, R. W. Quality control and benefication of fly ash. Paper in "Ash Utilization." U.S. Bureau of Mines, Information Circular 8488:151-164. 1970.

71. Thring, M. W. The science of flames and furnaces: 2nd ed. John Wiley and Sons, Inc., New York, N.Y. 1952 .

72. Tilley, G. S., Miller, R. W., and Ralston, O. C. Acid processes for the extraction of alumina. U.S. Bureau of Mines, Bulletin 267:2-85. 1927.

73. U.S. faces shortage of vital mineral sources. Chemical and Engineering News 53(8):15.: February 24, 1975.

74. Vogel, A. I. A test-book of quantitative inorganic analysis including elementary instrumental analysis. 3rd Edition. John Wiley and Sons, Inc., New York, N.Y. 1961 .

75. Walthall, J. H., Miller, P., and Striplin, M. M. Development of a sulfuric acid process for production of alumina from clay. Trans. AIChE 41:53-146. 1945.

76. Watt, J. D., and Thorne, D. J. Characteristics of fly ashes I. Journal of Applied Chemistry 15:585-594. 1965 .

77. Watt, J. D., and Thorne, D. J. Characteristics of fly ashes I. Journal of Applied Chemistry 15:595-604. 1965 . 
78. Weaver, J. B., and Bauman, H. C. Cost and profitabiltiy estimation. Section 25 in R. H. Perry and C. H. Chilton, eds. Perry's Handbook. 5th edition. McGraw-Hill Book Co., Inc., New York, N.Y. 1973.

79. Whittingham, $\dot{G}$. High temperature reactions of coal minerals during combustion. B.C.U.R.A. Monthly Bulletin 18:581-590. 1954.

80. Wicks, C. E., and Block, F. E. Thermodynamic properties of 65 elements - their oxides, halides, carbides, and nitrides. U.S. Bureau of Mines, Bulletin 605:1-146. 1963. 


\section{ACKNOWLEDGMENTS}

I would like to express my sincere gratitude to Dr. George Burnet for his time and assistance in this research. Dr. Burnet has provided his guidance and helpful commentary on all phases of work conducted.

I am also grateful to Mr. M. J. Murtha, Associate Engineer in the Chemical Engineering Division at the Ames Laboratory. His experience and counseling were certainly a big help in the completion of this work. 